\title{
Precursor and ambient rock paleothermometry to assess the thermicity of burial dolomitization in the southern Cantabrian Zone (northern Spain)
}

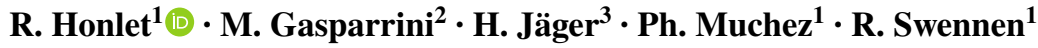

Received: 3 March 2017 / Accepted: 15 September 2017

(c) Springer-Verlag GmbH Germany 2017

\begin{abstract}
Paleozoic rocks in the Cantabrian Zone, and the Variscan foreland fold-and-thrust belt on the Iberian Peninsula have been affected by a sequence of diagenetic to epizonal thermal events. Late- to Post-Variscan hot fluid circulation caused a large-scale burial dolomitization and ore mineralization, mostly in Cambrian and a Lower to Middle Carboniferous carbonate sucessions. The goal of this study is to analyze and compare the temperatures experienced by the carbonate precursor rocks, as well as the under- and over-lying siliciclastic ambient rocks to gain a better understanding of the thermicity of dolomitization. These temperatures are evaluated based on published paleothermal datasets combined with new data obtained from Rock-Eval pyrolysis and vitrinite reflectance analysis of Carboniferous rocks rich in organic matter. The overall results indicate that reworking of detrital sediments in synorogenic ambient siliciclastics results in an anomalously high thermal maturity recorded by bulk rock techniques such as illite crystallinity and Rock-Eval pyrolysis. In situ VR-derived paleotemperatures recorded by ambient siliciclastic rocks appear to be higher compared to CAI-derived temperatures for carbonate precursor rocks. This variation in thermal maturity is likely related to the analytical techniques used to obtain CAI and VR data, and the empirical equations applied to
\end{abstract}

R. Honlet

robin.honlet@kuleuven.be

1 Department of Earth and Environmental Sciences, KU Leuven, Celestijnenlaan 200E, 3001 Heverlee, Belgium

2 Georesources Department, IFP Energies Nouvelles, Avenue de Bois-Préau, 1 and 4, 92852 Rueil-Malmaison Cedex, France

3 GeoResources STC, Im Neuenheimer Feld 234, 69120 Heidelberg, Germany calculate corresponding paleotemperatures. Conodont fragments were not as sensitive compared to vitrinite, and the color alteration process could have suffered from hydrothermal alteration. A secondary cause might be a different response to mechanical deformation between siliciclastic and carbonate units during the Variscan and post-Variscan geodynamic evolution of the study area. Rigid precursor carbonate units experienced fluid circulation mainly along distinct and spaced fracture zones, creating fracture-related dolomite geobodies and ore mineralization. Soft ambient siliciclastic rocks experienced more diffuse fluid circulation and heat dissipation. The different paleothermometry datasets compiled for the study area indicate that the fluids circulating during Late- to Post-Variscan times, with associated fracture-related dolomitization and ore mineralization in carbonate precursors, are hydrothermal. The highest paleotemperatures were recorded in ambient and precursor rocks in the highly tectonized northern part of the study area, where several thrusts and faults allowed intense fluid circulation. Positive temperature anomalies within the precursor carbonates correlate well with the occurrence of dolomite geobodies and ore mineral deposits. Such anomalies could thus be used as an exploration tool for hydrothermal dolomite bodies in analog sub-surface settings.

Keywords Paleothermometry - Cantabrian zone ·

Dolomitization $\cdot$ Rock-Eval pyrolysis $\cdot$ Vitrinite reflectance

\section{Introduction}

The Cantabrian Zone (CZ) in Northern Spain represents the Variscan foreland fold-and-thrust belt (FFTB) on the Iberian Peninsula. This most external zone of the Iberian Variscan Massif has been affected by several diagenetic to epizonal 
thermal events during its complex geodynamic evolution. Pre-Variscan burial metamorphism is responsible for the recorded thermal isograds in the northern and western $\mathrm{CZ}$ (Bastida et al. 1999; Brime et al. 2001). In the southern CZ, the burial metamorphism has been overprinted by two thermal events related to Late- to Post-Variscan orocline formation and subsequent lithospheric delamination (Raven and van der Pluijm 1986; Gutiérrez-Alonso et al. 2004; Aller et al. 2005). The latter induced the circulation of hot fluids in an extensional setting which caused massive fracture-related dolomitization of Paleozoic limestones, creating seismicscale porous dolomite geobodies (Gasparrini et al. 2006b; Lapponi et al. 2013; Muñoz Quijano 2015). These geobodies are now exposed and represent world class outcrop analogs for dolomitic subsurface oil and gas reservoirs elsewhere (Phipps 1989; Hurley and Budros 1990; Cantrell et al. 2004; Feng et al. 2016).

A variety of paleothermometers has been applied to deduce the thermal history of the $\mathrm{CZ}$, with the southern thrust units in particular. They include the conodont color alteration index (CAI; Raven and van der Pluijm 1986; Bastida et al. 1999; Brime et al. 2001; Aller et al. 2005), the Kübler Index (KI) of illite crystallinity (Brime 1981; Aller et al. 1987; Marschik 1992; Bastida et al. 1999; Brime et al. 2001), vitrinite reflectance analysis (VR; Colmenero and Prado 1993; Frings et al. 2004; Colmenero et al. 2008), fluid inclusion (FI) microthermometry (Paniagua et al. 1993; Ayllón et al. 2003; Gasparrini et al. 2006a; Lapponi et al. 2013; Muñoz Quijano 2015) and apatite fission-track (AFT) thermochronology (Carrière 2006; Botor and Anczkiewicz 2015). In the southern CZ, fracture-related dolomites, occurring mostly in Carboniferous carbonates, formed at temperatures between 130 and $150{ }^{\circ} \mathrm{C}$ (based on FI microthermometry; Gasparrini et al. 2006a). The dolomitization has been interpreted as hydrothermal (i.e. formed at temperatures at least $10{ }^{\circ} \mathrm{C}$ higher than those of the precursor carbonate rocks; sensu Machel and Lonnee 2002) based on CAI data from the Carboniferous precursors (Gasparrini et al. 2006b), indicating that they experienced maximum temperatures between 70 and $95{ }^{\circ} \mathrm{C}$ (Raven and van der Pluijm 1986). However, the temperatures derived from CAI data do not correspond to the common occurrence of ordered mixed-layer illite/smectite in ambient siliciclastic rocks of the southern $\mathrm{CZ}$, indicating temperatures above $100{ }^{\circ} \mathrm{C}$ (Eberl 1993; Brime et al. 2001; Aller et al. 2005). These observations highlight the need for a coherent interpretation of the paleothermal data available for the southern $\mathrm{CZ}$, to better constrain the thermal conditions of dolomitization, the diagenetic process of prime importance in this area. Up to date, most of the paleothermometers listed above have mainly been used to map isograds to understand the different metamorphic events which affected the CZ. A more exhaustive understanding of the thermal history experienced by the
Carboniferous precursor and ambient rocks in the southern $\mathrm{CZ}$ is thus necessary to address the thermal constraints of the dolomitization process in such a complex geodynamic setting.

The present study extends the published paleothermometry database by performing Rock-Eval (RE) pyrolysis and VR analysis on organic-rich clay- and mudstones from the Bodón Unit, a tectonostratigraphic unit in the southern CZ. The samples were taken from ambient siliciclastic rocks stratigraphically under- and over-lying the massive dolomitized carbonate units (Visean to Bashkirian), and the newly acquired data are integrated into the paleothermal framework of the southern CZ. The aim of this study is to deduce reliable maximum temperatures experienced by precursor and ambient rocks of the dolomite geobodies occurring in the study area, to improve the understanding of the paleothermal history of the southern $\mathrm{CZ}$, as well as the thermal conditions (geothermal versus hydrothermal) which governed the occurrence of the massive dolomitization. Finally, the regional distribution of the thermal maturity of precursor and ambient rocks was compared to the regional distribution of hydrothermal dolomite geobodies, which allowed correlating the spatial occurrence of dolomites with thermal anomalies in precursor and ambient rocks. This represents a potential new approach to detect hydrothermal subsurface geobodies in hydrocarbon and geothermal exploration plays.

\section{Geological setting}

\section{Geodynamic history of the Cantabrian zone (CZ)}

The Cantabrian Mountains of Northern Spain consist of Paleozoic sedimentary rocks, locally covered by minor Mesozoic and Cenozoic successions. These Paleozoic rocks represent the FFTB of the Iberian Variscan Massif, referred to as the Cantabrian Zone (Julivert 1971; Fig. 1a).

The Variscan Orogeny developed a N-S oriented eastverging thin-skinned mountain range, which evolved into a secondary thick-skinned orocline during the Upper Carboniferous (ca. 310-295 Ma; Gutiérrez-Alonso et al. 2004, 2012, 2015; Weil et al. 2013). The lithospheric root underneath the orocline center, roughly corresponding to the $\mathrm{CZ}$, thickened, became unstable and lithospheric delamination occurred (ca. 295-285 Ma; Gutiérrez-Alonso et al. 2004, 2012). The delaminating lithosphere was replaced by upwelling asthenospheric material resulting in extension and increased crustal heat flow (Gutiérrez-Alonso et al. 2004; Weil et al. 2013).

Precambrian rocks exposed in the core of the Narcea Antiform (Fig. 1a) separate the CZ from the metamorphic internal zones of the Variscan Orogen, located to the 


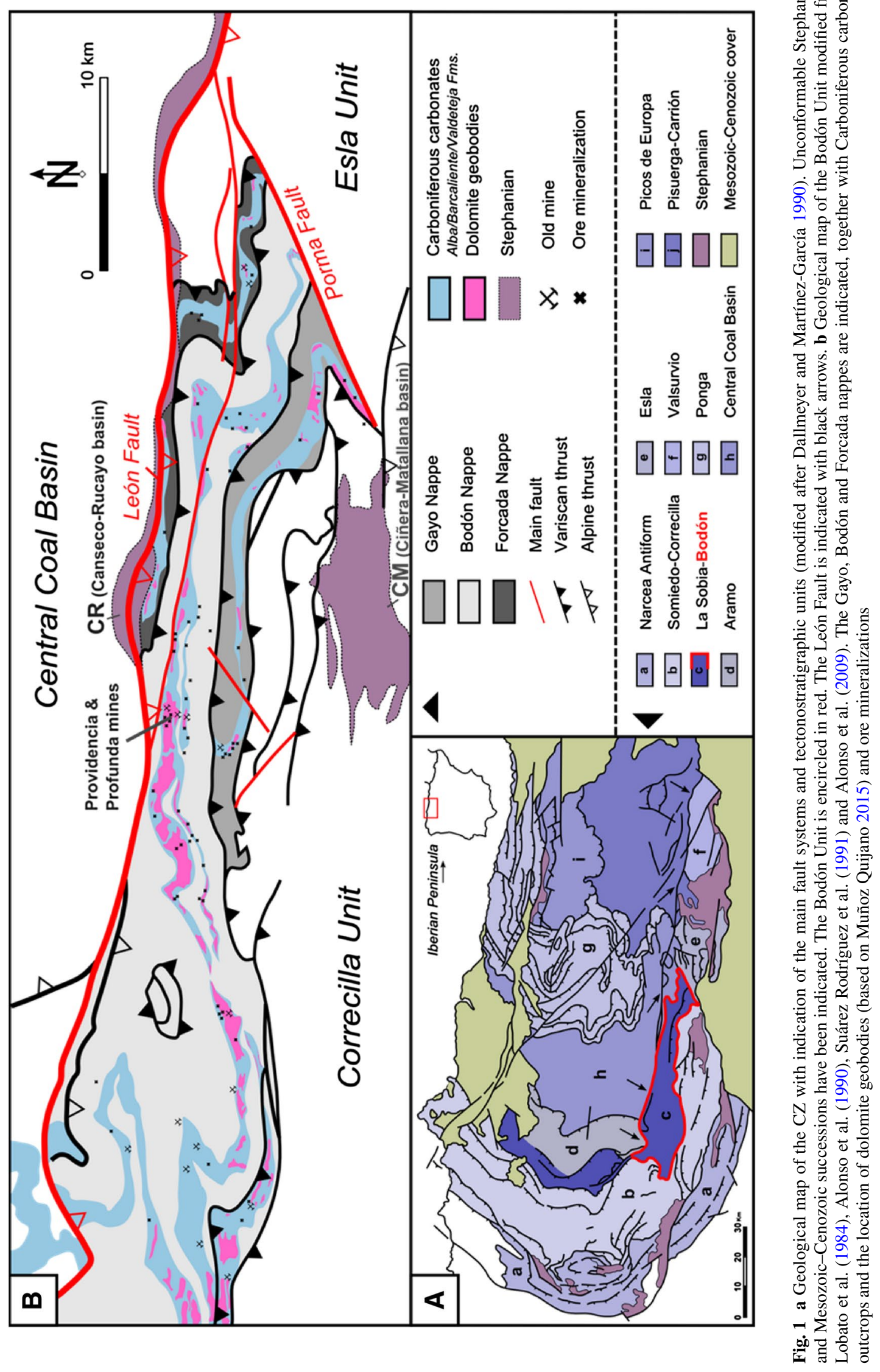


southwest. The CZ is subdivided into several tectonostratigraphic units (Julivert 1971; Pérez-Estaun et al. 1988; Fig. 1a): the Somiedo-Correcilla, La Sobia-Bodón, Aramo, Esla, Valsurvio, Ponga, Central Coal Basin, Picos de Europa and Pisuerga-Carrión units. The Somiedo-Correcilla and La Sobia-Bodón units are often subdivided into the Somiedo and Correcilla units and the La Sobia and Bodón units, respectively. This study is focused on the Bodón Unit, located south of the León Fault (a major tectonic lineament that crosscuts a large part of the CZ: Fig. 1a, b). Recently, the classical subdivision of the $\mathrm{CZ}$ has been modified by Alonso et al. (2009), based on a new interpretation of the León Fault, being an out-of-sequence breaching thrust, duplicating tectonic units. However, in this contribution the former subdivision is used, to enable the correlation of the new thermal data obtained from this study with thermal data from previous studies. The Bodón Unit is subdivided into three structural nappes: the Gayo, Bodón and Forcada nappes (Evers 1967; Marcos 1968; Fig. 1b).

During the Cretaceous, an extensional episode occurred related to the opening of the northern Atlantic Ocean and the Bay of Biscay located northeast of the CZ (Gong et al. 2008). Overall, the extensional tectonics affecting the $\mathrm{CZ}$ at the end of the Paleozoic and during the Mesozoic are not well constrained due to a lack of preserved sediments (Martín-González et al. 2012).

The last tectonic event that affected the $\mathrm{CZ}$ is related to the Alpine Orogeny, leading to uplift and exhumation of the Variscan basement (Alonso et al. 1996; Fillon et al. 2016). This created much of the present topography (i.e. the Cantabrian Mountains). The Alpine Orogeny caused minor internal deformation in the $\mathrm{CZ}$, except for the slight reactivation of faults and thrusts, block tilting and some further shortening (Pulgar et al. 1999).

\section{Stratigraphy of the Bodón unit}

In the Bodón unit, as in most tectonostratigraphic units of the western and southern $\mathrm{CZ}$, Paleozoic rocks were thrust along a décollement level located in carbonate rocks of the Lower Cambrian Láncara Fm. (Julivert 1971). The CZ is subdivided into a pre-orogenic (pre-Carboniferous) and a synorogenic rock succession (Carboniferous), developed during the Variscan Orogeny (Marcos and Pulgar 1982; Fig. 2). Due to the Variscan and Alpine compression, the rock successions in the Bodón Unit were tilted and presently dip subvertically, leading to excellent outcropping conditions, particularly along road cuts (Fig. 3).

The Láncara Fm. consists of limestones with a lower member composed of synsedimentary to early diagenetic dolomite (Zamarreño 1972). Upper Cambrian to Silurian deposits are composed of siliciclastic rocks, with the Silurian Formigoso Fm. composed of dark shales. The
Devonian is characterized by an alternation of carbonates and siliciclastic rocks, with the La Vid Group representing the thickest stratigraphic unit (Fig. 3a). The Ermita Fm. is a transgressive sandstone unit of a few meters thick, deposited during the Upper Devonian (Fig. 3a). The Vegamián Fm. at the base of the Lower Carboniferous is a thin succession (5-10 m) of black shales and siltstones with phosphate, manganese, markasite and chert nodules (Fig. 3a). Thin silt- to sandstone intercalations can occur, as well as carbonate lenses of a few $\mathrm{cm}$ in thickness. The Vegamián Fm. was deposited below wave base at low sedimentation rates under anoxic conditions (Raven 1983). Seibert (1986) correlates the deposition of the Vegamián Fm. with eustatic sea-level rise and subsidence. The Vegamián Fm. represents the transition to thick carbonate successions filling the Variscan foreland basin during the Lower to Middle Carboniferous (Bahamonde et al. 2015). These successions are divided into three formations: the Alba, Barcaliente and Valdeteja fms. The Alba Fm. (Late Tournaisian to Late Serpukhovian) is usually less than $30 \mathrm{~m}$ in thickness and is composed of two nodular limestone packages, interpreted as condensed units deposited on a well oxygenated carbonate platform (Fig. 3a). A member composed of bedded cherts can be found between these limestone packages and represents an episode of pelagic sedimentation (Wagner et al. 1971; Sanchez de Posada et al. 1990). The overlying Barcaliente Fm. (Late Serpukhovian to earliest Bashkirian) is composed of thinly bedded dark mudstones showing a remarkable consistency in both thickness (ca. $300 \mathrm{~m}$ ) and depositional facies over most of the CZ. It reflects a period of uniform carbonate sedimentation in a shallow water, low energy, anoxic environment (Evers 1967; Wagner et al. 1971; Dietrich 2005). The Bashkirian Valdeteja Fm. (up to 1500 m thick) is made of massive carbonates deposited in a shallow marine platform environment (Winkler Prins 1968; Wagner et al. 1971; Dietrich 2005; Chesnel et al. 2015; Fig. 3b), whose sedimentation is strongly influenced by the approaching Variscan orogenic front. The Valdeteja Fm. is diachronically overlain by siliciclastic rocks of the Late Bashkirian to Early Moscovian San Emiliano Fm. (Lobato et al. 1984; Alonso et al. 1990; Fig. 3b), which filled up the foredeep of the Variscan Orogen (Brouwer and van Ginkel 1964). It is composed of claystones (Fig. 3c), locally with abundant sandstone and carbonate lenses, and coal seams (van Ginkel 1965; Wagner and Bowman 1983; Eichmüller 1985; Samankassou 2001). Unconformable Stephanian siliciclastic successions occur in local intramontane pull-apart basins (Fig. 1a), of which the Ciñera-Matallana (CM) and Canseco-Rucayo (CR) basins are located closest to the Bodón Unit (Colmenero et al. 2008; Fig. 1b). Permian to Cretaceous sediments are absent in the southern $\mathrm{CZ}$ and crop out only locally in the northern CZ (Dalmeyer and 
Fig. 2 Stratigraphic column of the Bodón Unit [modified from Aller et al. (2005) and PérezEstaún et al. (1988)] showing Carboniferous precursor carbonate successions in light blue and dolomite geobodies in pink. Stephanian siliciclastics are indicated in purple. Preorogenic and synorogenic successions are distinguished, as well as what is here referred to as dolomite precursor carbonate rocks and ambient siliciclastic rocks. The stratigraphic intervals sampled for the different published paleothermometry datasets and sampled for this study are shown on the right

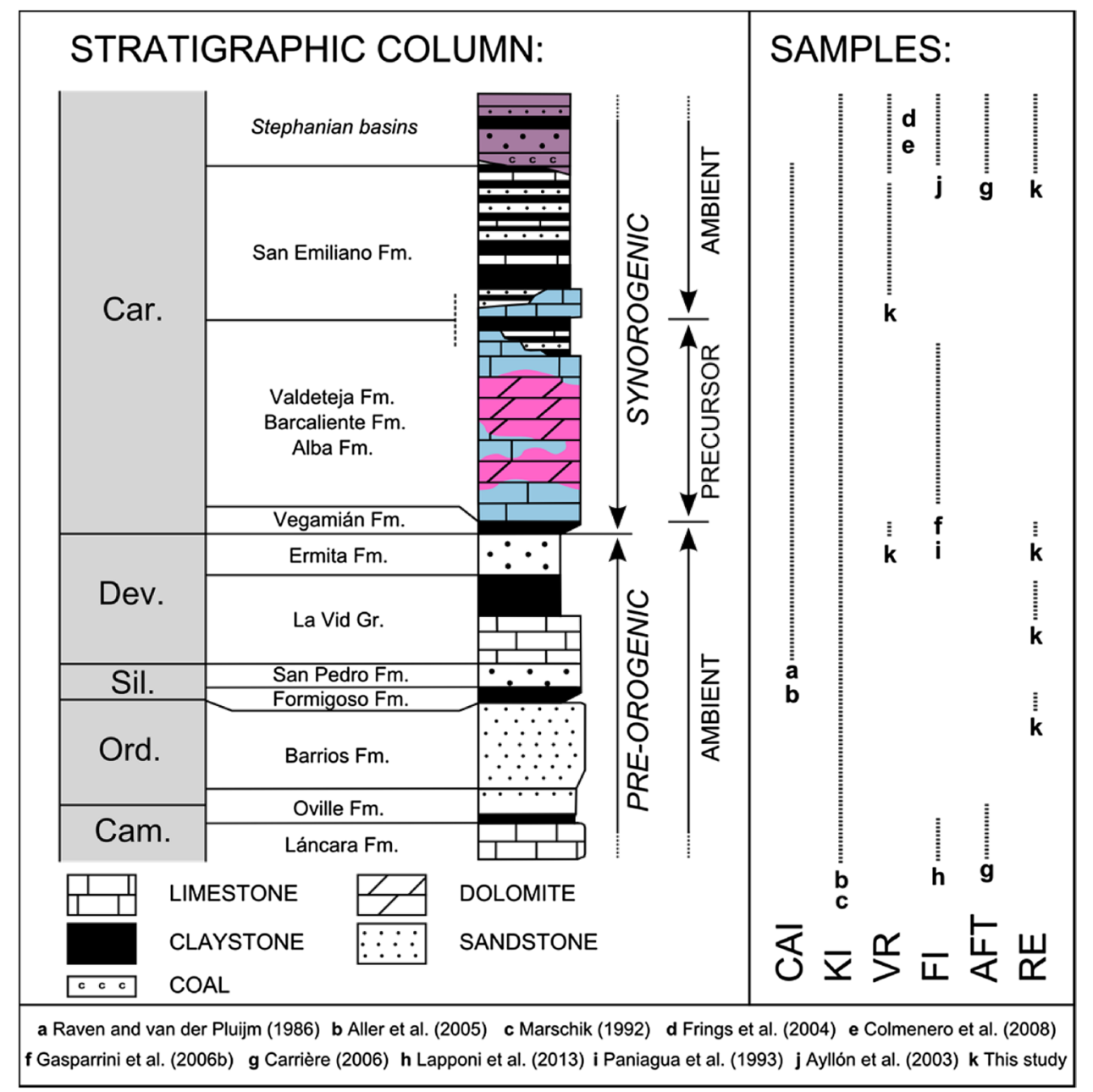

Martínez-García 1990; Fig. 1a). They might have been initially deposited and eroded later on (Alonso et al. 1996; Gómez-Fernández et al. 2000; Frings et al. 2004; Botor 2012).

In the Bodón Unit, fracture-related dolomitization mostly affected the Barcaliente and Valdeteja Fms. (Gasparrini et al. 2006b; Muñoz Quijano 2015; Fig. 3d). Smaller dolomite geobodies occur in the Láncara Fm. (Lapponi et al. 2013) and in the top layers of the Alba Fm. (Gasparrini et al. 2006b). Detailed petrographic descriptions of dolomite exposed in the Bodón Unit have been made by Gasparrini et al. (2006b) and Lapponi et al. (2013). Both studies describe dolomite rocks with a typical succession of replacive and void-filling dolomite, followed by calcite cementation. Based on the work of Muñoz Quijano (2015) combined with the results from aerial photographs and mapping, the occurrence of dolomite geobodies in Carboniferous carbonates is indicated in Fig. 1b. Important ore mineralizations post-date dolomitization, as ore minerals occur in pores and cavities created by the dolomitization process (Paniagua et al. 1993; Gasparrini et al. 2006b).

\section{Thermal history of the $\mathrm{CZ}$}

The Paleozoic rocks of the CZ have been affected by several thermal episodes related to the complex geodynamic history of the area (Bastida et al. 2002). Peak burial prior to the onset of Variscan thrusting was the most important process causing the metamorphic grades recorded by the Paleozoic rocks in most of the CZ (Bastida et al. 2002; Aller et al. 2005). This is indicated by the following: (1) metamorphic grades increase with rock age, (2) the distribution of metamorphic grades is not influenced by major thrusts and (3) metamorphic patterns are discontinuously inverted (i.e. rocks recording higher metamorphic grades are thrust over rocks recording lower metamorphic grades; Brime 1981; Bastida et al. 1999; Aller et al. 2005). Burial resulted in diagenetic (up to $200{ }^{\circ} \mathrm{C}$ ) to locally anchizonal (200-300 ${ }^{\circ} \mathrm{C}$ ) conditions. The thermal peak occurred when the Paleozoic successions reached their maximum thickness (Bashkirian-Moscovian), preceding the emplacement of the tectonostratigraphic units (Bastida et al. 2002). Based on CAI data from Devonian rocks in the Somiedo Unit, a paleogeothermal gradient of about $35{ }^{\circ} \mathrm{C} / \mathrm{km}$ is 

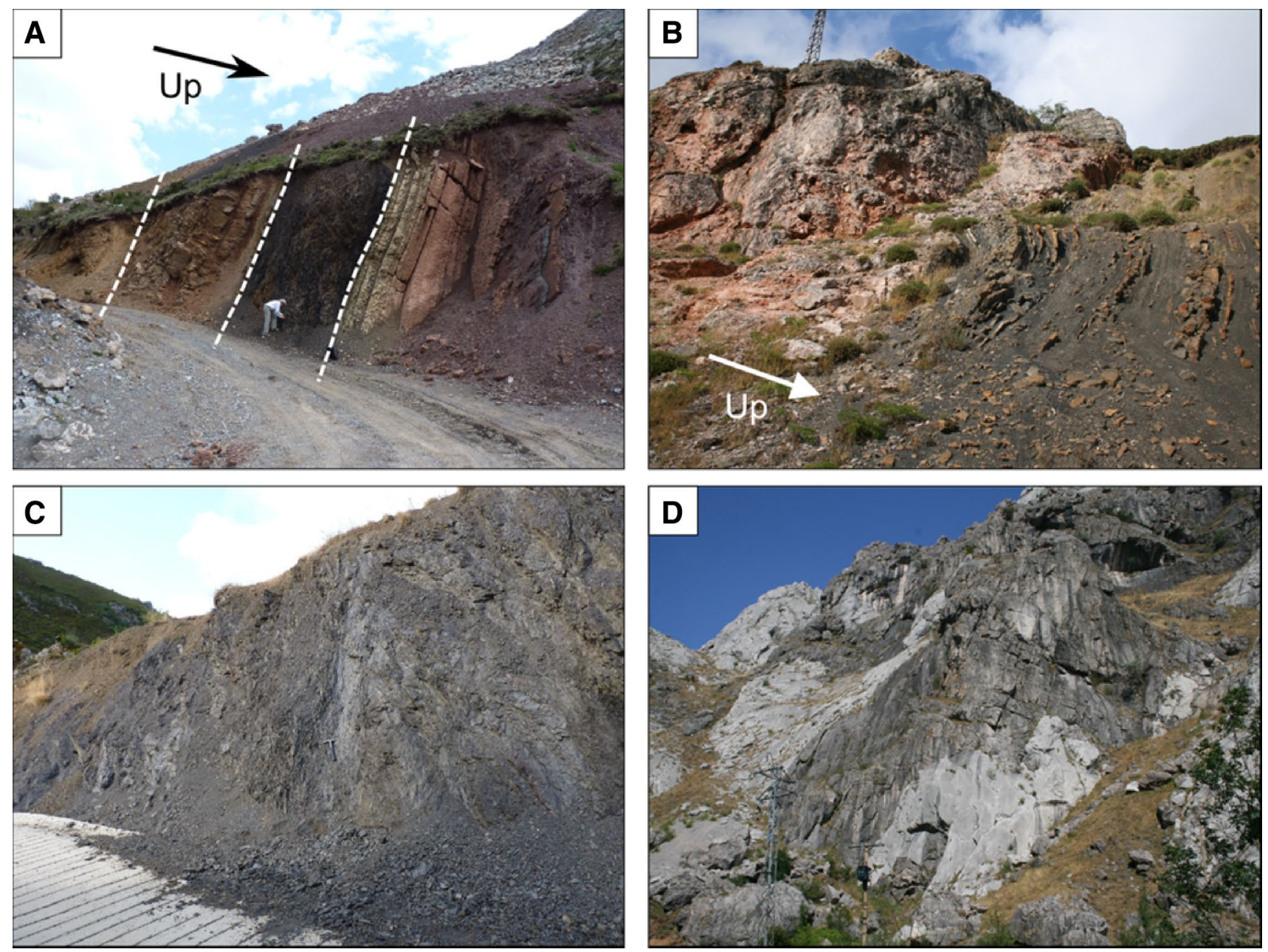

Fig. 3 a Exposure of Upper Devonian and Lower Carboniferous successions in the Las Chábanos quarry in the northern central part of the Bodón Unit. Formation boundaries are indicated with white dotted lines. Siliciclastic rocks of the Devonian La Vid Group are exposed on the far left, followed by brownish sandstone beds of the Ermita Fm. The black succession in the center of the picture represents the Lower Carboniferous Vegamián Fm. which is overlain by nodular limestones of the Alba Fm. On the far right side, the central chert member of the Alba Fm. can be seen. Note professor for scale.

b Diachronic contact between Valdeteja limestones (left) and San Emiliano clay- and sandstones (right) in the central part of the Bodón Unit. Note utility pole on top for scale. c Typical exposure of San Emiliano Fm. claystones, characterized by the occurrence of diffuse tectonic cleavage. Note hammer for scale. d Example of dolomitized limestones of the Valdeteja Fm. in the southeastern part of the Bodón Unit. Light gray rocks are the precursor limestones, whereas dark gray rocks are dolomites. Note utility poles on lower left side for scale

estimated for this episode of peak burial (Brime et al. 2001).

Regional orogenic metamorphism, due to Variscan folding and thrusting, has only locally been recognized in the CZ (Bastida et al. 2002). It is generally recorded closer to the internal areas of the Variscan Orogeny (e.g. in the northwestern part of the Somiedo unit; Brime et al. 2001). It is of minor importance in the southern $\mathrm{CZ}$ and did not affect the Paleozoic rocks presently exposed in the Bodón unit (Bastida et al. 2002; Aller et al. 2005).

Lithospheric delamination, initiated after the orocline formation, led to the upwelling of the asthenosphere and to a concomitant increase in crustal heat flow (Gutiérrez-Alonso

et al. 2004; Weil et al. 2013). The upwelling also caused uplift of the CZ, accompanied by near-surface extension (Muñoz-Quijano and Gutiérrez-Alonso 2007). Two thermal events have been recognized in the $\mathrm{CZ}$, corresponding respectively to the orocline formation and the subsequent lithospheric delamination, both accompanied by dominant extensional tectonics (Bastida et al. 2002; Aller et al. 2005).

The first event, often referred to as the Late-Variscan extensional event (Bastida et al. 2002) and likely associated with the orocline formation, has been recorded in the southern part of the Central Coal Basin and in the Pisuerga-Carrión and Valsurvio units (Aller and Brime 1985; Aller et al. 1987; Bastida et al. 2002). Here, the 
Paleozoic rocks record anchizonal to locally epizonal conditions (above $300{ }^{\circ} \mathrm{C}$ ) typically associated with subhorizontal cleavage, as a result of extensional tectonics (Aller et al. 1987; Marín 1997; García-López et al. 1999). The distribution of both anchizonal and epizonal metamorphism (affecting pre-Permian rocks only), as well as the cleavage development, do not correspond to the location of the main Variscan structures. Intrusions of small sills and stocks, which occur mainly in the western and eastern units of the CZ (Corretgé and Suárez 1990), accompanied this event. Close to these intrusions, contact metamorphism resulted in epizonal grades and the development of skarn deposits (Bastida et al. 2002 and references therein). Since subhorizontal cleavage associated with high metamorphic grades or intrusions has not been reported in the Bodón Unit (Aller et al. 1987), the Late-Variscan extensional event was likely of minor importance.

The second thermal event, referred to as the PostVariscan thermal event (Bastida et al. 2002), was responsible for the widespread occurrence of fracture-related dolomitization and ore mineralization in Paleozoic successions (Martínez-García 1983; Gómez-Fernández et al. 2000; Crespo et al. 2000; Gasparrini et al. 2006b; Muñoz-Quijano and Gutiérrez-Alonso 2007). Several anomalies in CAI values occur within the Bodón and Picos de Europa units, in the areas with dense fault patterns and abundant ore mineralization, and are interpreted to be caused by hot fluid movements during this thermal episode (Raven and van der Pluijm 1986; Bastida et al. 2002). In the southern CZ, anchi- to epizonal conditions recorded in the Stephanian pull-apart basins are probably related to intrusions of diorite during the same thermal episode (Bastida et al. 2002). These intrusions resulted in re-equilibration of fluid inclusions in quartz veins in the CM Basin (Ayllón et al. 2003). The Post-Variscan thermal event is dated at $270 \mathrm{Ma}$ based on $\mathrm{K}$-Ar ages from illite (Weh et al. 2001). These ages correspond with $\mathrm{U}-\mathrm{Pb}$ and $\mathrm{Pb}-\mathrm{Pb}$ absolute dating of dolomite-hosted ore minerals from the Bodón Unit (Paniagua et al. 1993). Therefore, the Post-Variscan thermal event correlates temporally with lithospheric delamination following the orocline formation. Lithospheric delamination induced the circulation of hot and hypersaline marine-derived brines, modified through water-rock interactions, representing the source of $\mathrm{Mg}$ for massive dolomitization (Gasparrini et al. 2006a, b; Lapponi et al. 2013). Based on AFT thermochronology, Carrière (2006) and Botor and Anczkiewicz (2015) concluded that although this thermal event was likely short-lived, temperatures remained high within Stephanian siliciclastic successions (above $60^{\circ} \mathrm{C}$ ), at least until the Middle Triassic.

\section{Materials and methods}

\section{Published paleothermometry database}

In the following sections, the different paleothermometry datasets published for the Bodón unit in previous studies are introduced. The stratigraphic intervals sampled for each paleothermometer are indicated on the stratigraphic column of Fig. 2. A brief explanation of the different paleothermometers is followed by an explanation on how the raw data have been converted to paleotemperatures. Most of the introduced paleothermometers are strongly affected by the duration of a thermal event, which has to be taken into account when comparing different paleothermal datasets. What also needs attention, is the fact that some datasets are available only from the precursor carbonate successions while others are derived from the siliciclastic ambient rocks. The calculated paleotemperatures have to be handled with care, because the empirical equations used for the different datasets have a specific accuracy and uncertainty regarding the parameters and preconditions applied, which might be a source of error and inaccuracy.

\section{Conodont color alteration index (CAI)}

The color alteration of conodonts depends on the carbonization of organic matter (OM) traces and is controlled by maximum temperature and heating time (Epstein et al. 1977; Rejebian et al. 1987). Recalculated paleotemperatures are strongly influenced by the duration of the heating event, as a relatively long heating time is required for the carbonization of organic matter in conodonts. Confining pressure does not affect the alteration process, excluding tectonics from influencing the color of conodont fragments (Epstein et al. 1977). Nevertheless, the presence of fluids under pressure, which is important in hydrothermal systems, can retard alteration. In such settings, OM carbonization is replaced by oxidation and volatilization of oxides, resulting in a loss of OM which affects the color alteration (Epstein et al. 1977; Rejebian et al. 1987).

CAI data were obtained by Raven and van der Pluijm (1986) and Aller et al. (2005) and are derived from conodonts found in Devonian and Carboniferous rock successions. The data have been converted to temperature using the Arrhenius plot constructed by Epstein et al. (1977). A heating time of $10 \mathrm{Ma}$ was used to convert the CAI data, based on the AFT studies of Carrière (2006), and Botor and Anczkiewicz (2015).

Kübler index (KI) of illite crystallinity and clay mineralogy

The KI of illite crystallinity allows the determination of the kinetic clay mineral reaction progress in pelitic sequences. 
The crystallinity of illite is determined by measuring the full width at half maximum height of the illite (001) X-ray diffraction peak (Kübler 1967, 1968). Measurements are performed on oriented mineral aggregate samples of the $<2 \mu \mathrm{m}$ grain size fractions. Increasing crystallinity results in decreasing KI values. Despite the important role of temperature in the reaction process of phyllosilicates, numerous other factors (such as permeability, potassium availability, weathering, and mechanical and hydrothermal alteration) affect the crystallinity of illite (e.g. Junfeng and Browne 2000; Frings and Warr 2012; Fukuchi et al. 2014). As a result, phyllosilicates in diagenetic conditions often reflect clay mineral reaction progress instead of thermodynamic equilibrium, which makes the use of the KI paleothermometerically problematic (Guggenheim et al. 2002).

Despite the many factors possibly influencing the crystallinity of illite, general correlation charts (e.g. Merriman and Frey 1999; Voldman et al. 2008) estimate that KI values lower than 0.42 correspond to temperatures above $200{ }^{\circ} \mathrm{C}$ (anchizone), whereas KI values lower than 0.25 correspond to temperatures above $300{ }^{\circ} \mathrm{C}$ (epizone). Marschik (1992) and Aller et al. (2005) analyzed the clay mineralogy and KI of clay-rich siliciclastic rocks in the Bodón and Correcilla units, ranging from Cambrian to Carboniferous in age. Corresponding temperatures were calculated using the empirical formula of Mukoyoshi et al. (2007). This equation has been established based on a correlation between VR and KI data in an accretionary complex in southwest Japan, and has been applied with extreme caution.

Eberl (1993) identified three reaction zones for illite formation with the third zone corresponding to temperatures of at least $100{ }^{\circ} \mathrm{C}$. Clay mineralogy of samples from the Bodón Unit suggests that all mixed-layer illite/smectite in the samples used for KI measurements appears to be ordered (e.g. Brime et al. 2001 and; Aller et al. 2005). This indicates that zone 3 of Eberl (1993) was reached (Brime et al. 2001; Aller et al. 2005).

\section{Vitrinite reflectance (VR) analysis}

Due to changes in optical properties, the reflectance of vitrinite increases with increasing temperature in a predictable manner (Karweil 1955; Suggate 1959; Teichmüller 1982). Although suppression or retardation of vitrinite reflectance can occur under certain circumstances (e.g. in case of overpressure; Schito et al. 2016), the analysis of vitrinite reflectance is considered a reliable paleothermometric technique to assess the thermal maturity of sediments in diagenetic settings (Teichmüller 1987).

Published VR data are only available for the Stephanian CM (Frings et al. 2004; Colmenero et al. 2008) and CR (Colmenero et al. 2008) basins. They have been converted to temperature by applying the formula proposed by
Barker and Pawlewicz (1994) which, according to Frings et al. (2004), yields the most realistic temperatures for samples from the Stephanian CM basin.

\section{Fluid inclusion (FI) microthermometry}

FIs are tiny vacuoles of fluid trapped in crystals during mineral precipitation (Goldstein and Reynolds 1994). They provide information on the composition and temperature of the motherfluids through microthermometric measurements. Of most importance for this study is the homogenization temperature (Th), which gives an estimation of the minimum trapping temperature of an inclusion. By applying a pressure correction, the true formation temperature of crystal precipitation can be derived from Th.

Primary FIs in fracture-related dolomites occurring in both Cambrian and Carboniferous precursors have been investigated in previous studies (Gasparrini et al. 2006a; Lapponi et al. 2013; Muñoz Quijano 2015), as well as FIs in late diagenetic calcite are supposed to have precipitated from the same fluid system (Gasparrini et al. 2006a). FIs in quartz gangue minerals from ore deposits of the Providencia and Profunda mines (Fig. 1b) have been investigated by Paniagua et al. (1993). Ayllón et al. (2003) performed a microthermometric study on quartz veins in the Stephanian CM Basin.

\section{Apatite fission-track (AFT) thermochronology}

Fission-track thermochronology is a suitable technique to investigate the low-temperature thermal history of sedimentary rocks (Price and Walker 1963; Wagner and van den Haute 1992). The technique is based on the natural decay of ${ }^{238} \mathrm{U}$ isotopes, producing radiation damage trails (so-called fission-tracks) in U-bearing minerals. The spontaneous fission of ${ }^{238} \mathrm{U}$ isotopes produces fission tracks at a continuous rate throughout geological time. Fission-track thermochronology is mostly performed on apatite crystals (AFT thermochronology). Apatite fission tracks can undergo partial annealing (i.e. resetting) in a temperature range of 60 to $110 \pm 10^{\circ} \mathrm{C}$, due to a measurable shortening of the fission tracks at these temperatures (Gleadow and Duddy 1981). Complete annealing of fission tracks in apatite crystals occurs at temperatures higher than $110 \pm 10^{\circ} \mathrm{C}$ for $10 \mathrm{Ma}$.

Carrière (2006) successfully deduced the thermal history for two Cambrian and one Stephanian sample in or close to the eastern part of the Bodón unit. Recently, Botor and Anczkiewicz (2015) investigated the thermal history of the Stephanian Sabero Coalfield (located at southeast of the study area) through a combination of AFT thermochronology and VR analysis. 


\section{Rock-Eval (RE) pyrolysis and vitrinite reflectance (VR) analysis}

In addition to the published paleothermal datasets introduced above, the thermal maturity of a new set of samples was investigated through RE pyrolysis and VR analysis. A total of 78 samples of OM-rich clay- and mudstones from different stratigraphic levels were collected from road cuts and quarries. Most of the samples were collected in the Bodón Nappe (Fig. 1b). Other samples were collected in the Forcada and Gayo nappes, north of the León Fault (in the central coal basin as well as in the Stephanian CR basin) and in the northern part of the Correcilla Unit. Fresh material was preferentially sampled to minimize the influence of weathering (cfr. Copard et al. 2002).

RE pyrolysis is an analytical method used to characterize source rocks and evaluate their petroleum potential. It is based on the relative contents of free hydrocarbons and $\mathrm{CO}_{2}$ generated during pyrolysis, which is artificial heating of a sample (Espitalié et al. 1977, 1985a, b, c). Pyrolysis of the collected samples was performed using the Rock-Eval 6 apparatus (Lafargue et al. 1998) which employs a temperature-programmed heating of a powdered sample $( \pm 100 \mathrm{mg})$ in an inert atmosphere (helium or nitrogen). The sample is first placed in a pyrolysis oven to measure the quantity of free hydrocarbons (revealed by the so-called $S_{1}$ peak). Heating up to $650{ }^{\circ} \mathrm{C}$ allows the determination of the amount of hydrocarbons $\left(\mathrm{S}_{2}\right.$ peak) and $\mathrm{CO}_{2}\left(\mathrm{~S}_{3}\right.$ peak) produced during thermal cracking of kerogen. The sample is then transferred to an oxidation oven where the residual organic carbon, remaining in the sample after pyrolysis, is oxidized (and revealed by the $\mathrm{S}_{4}$ peak) at temperatures up to $850{ }^{\circ} \mathrm{C}$. In this way, the total organic carbon (TOC) content of the sample can be quantified. Of particular interest for this study is the Tmax parameter which corresponds to the $S_{2}$ peak temperature in the pyrolysis oven, which is used to estimate the thermal maturity of rocks (Tissot and Welte 1978). In this study, Tmax values were converted to equivalent VR values (referred to as Tmax-derived VR values) using the equation of Jarvie et al. (2001). RE pyrolysis produced reliable results for 55 samples, which are listed in Table 1 . The other samples (including all samples from the Alba, Barcaliente and Valdeteja fms.) were excluded due to low TOC values $(<0.3 \%)$ which have a high risk to produce unreliable RE pyrolysis data. From the 55 productive samples, 40 are from OM-rich layers of the San Emiliano Fm. In the Central Coal Basin, north of the León Fault, five samples are from the Lena and Sama Groups (local equivalents of the San Emiliano Fm.) and two samples are from the CR Basin. The remaining eight samples were collected from the Formigoso (two samples) and Vegamián fms. (four samples), from the La Vid Group (one sample) and from the Stephanian CM Basin (Roguera Fm.; one sample).
VR analysis, including specific maturity analysis of dispersed kerogen, was performed on 18 samples out of the 55 productive RE samples of the San Emiliano (15 samples) and Vegamián fms. (three samples; Table 1) through a method specifically applied at the GeoResources STC lab. The samples cover a wide range of TOC and Tmax values to evaluate the consistency between results from RE pyrolysis and VR analysis. Most samples are located within the Bodón Nappe and only one is located in the Forcada Nappe. Kerogen was isolated by the maceration technique (double acid treatment with $\mathrm{HCl}$ and $\mathrm{HF}$ ), and concentrated and embedded in epoxy resin blocks, which were polished on the surface for reflectance analysis. VR analysis is based on digital image analysis, using high-resolution black/white images of vitrinite, obtained with a reflected-light microscope. Gray levels of the digital images represent the levels of reflectance and are recalculated to real VR values by specifically modified image analysis software. This enables high-resolution reflectance analysis of single vitrinite grains down to pixelsize $(<10 \mu \mathrm{m})$ providing highly accurate and reliable VR data, without any correction factor needed. It also supports the identification of in situ versus reworked and degraded vitrinite in mixed vitrinite assemblages and the separation of real vitrinite from vitrinite-like particles. In each sample, 50 vitrinite particles were measured, if available. Additionally, one kerogen slide was made from each sample for optical analysis of kerogen composition, particularly the composition of the vitrinite assemblage, which was included in the detailed interpretation of the VR data. For the calculation of exact paleotemperatures from VR data, several equations can be used, leading to different paleotemperatures, with increasing variation towards higher maturation (Table 2). In this study, the equation of Barker and Pawlewicz (1994) was used to provide the maximum comparability between the new data of this study and the previous data by Frings et al. (2004).

\section{Results}

In the following sections the paleotemperatures obtained from literature datasets and from RE and VR measurements are reported. The regional distribution of paleotemperatures, calculated from each technique, is indicated on the geological map of the Bodón Unit (Figs. 4, 5).

\section{Published paleothermometry database}

CAI data for Devonian and Carboniferous successions in the Bodón Unit range from 1 to 5 (Raven and van der Pluijm 1986; Aller et al. 2005), corresponding to a wide range of diagenetic to anchizonal temperatures. The temperatures average around $60{ }^{\circ} \mathrm{C}$ for the Carboniferous precursor 


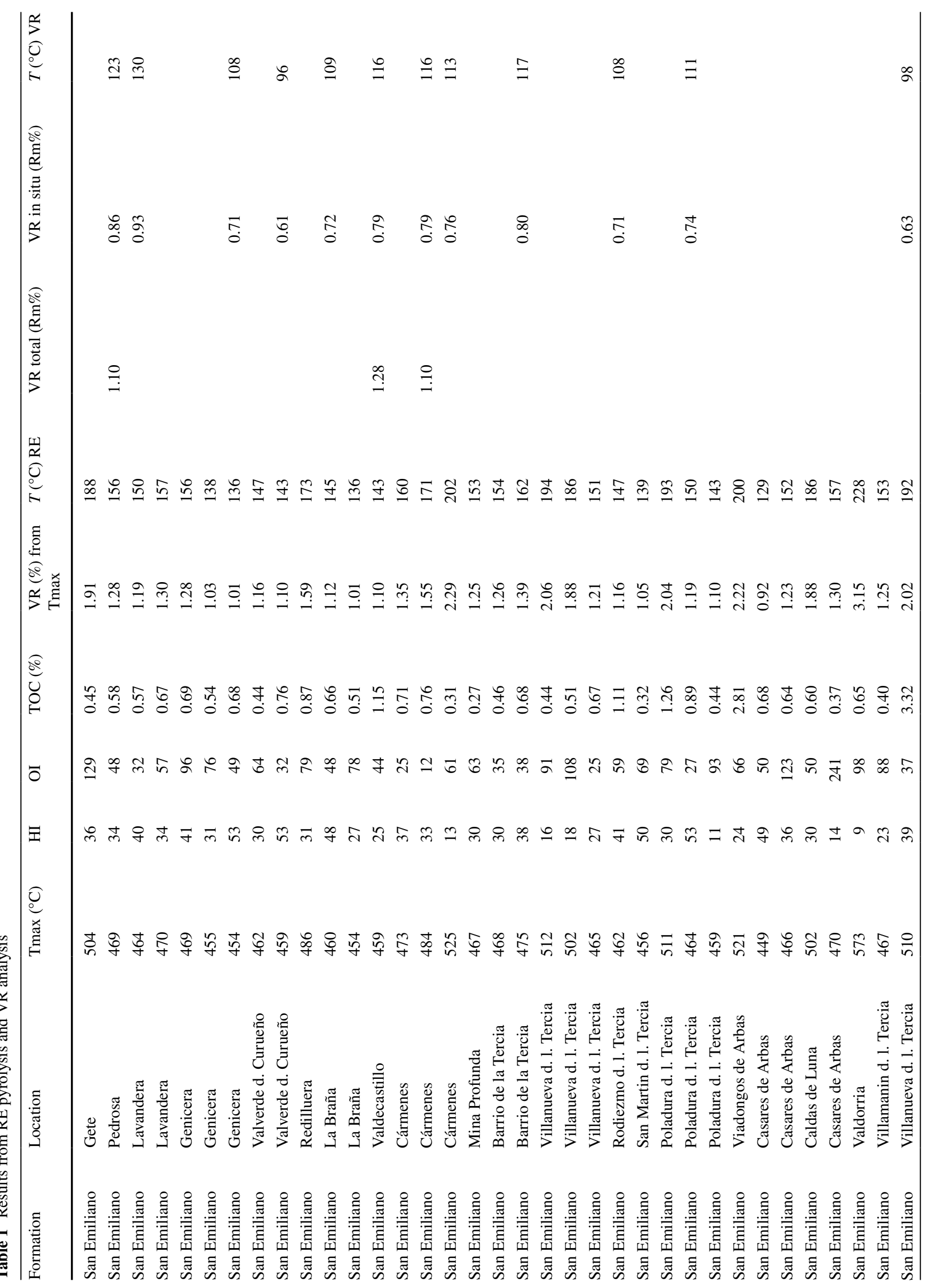




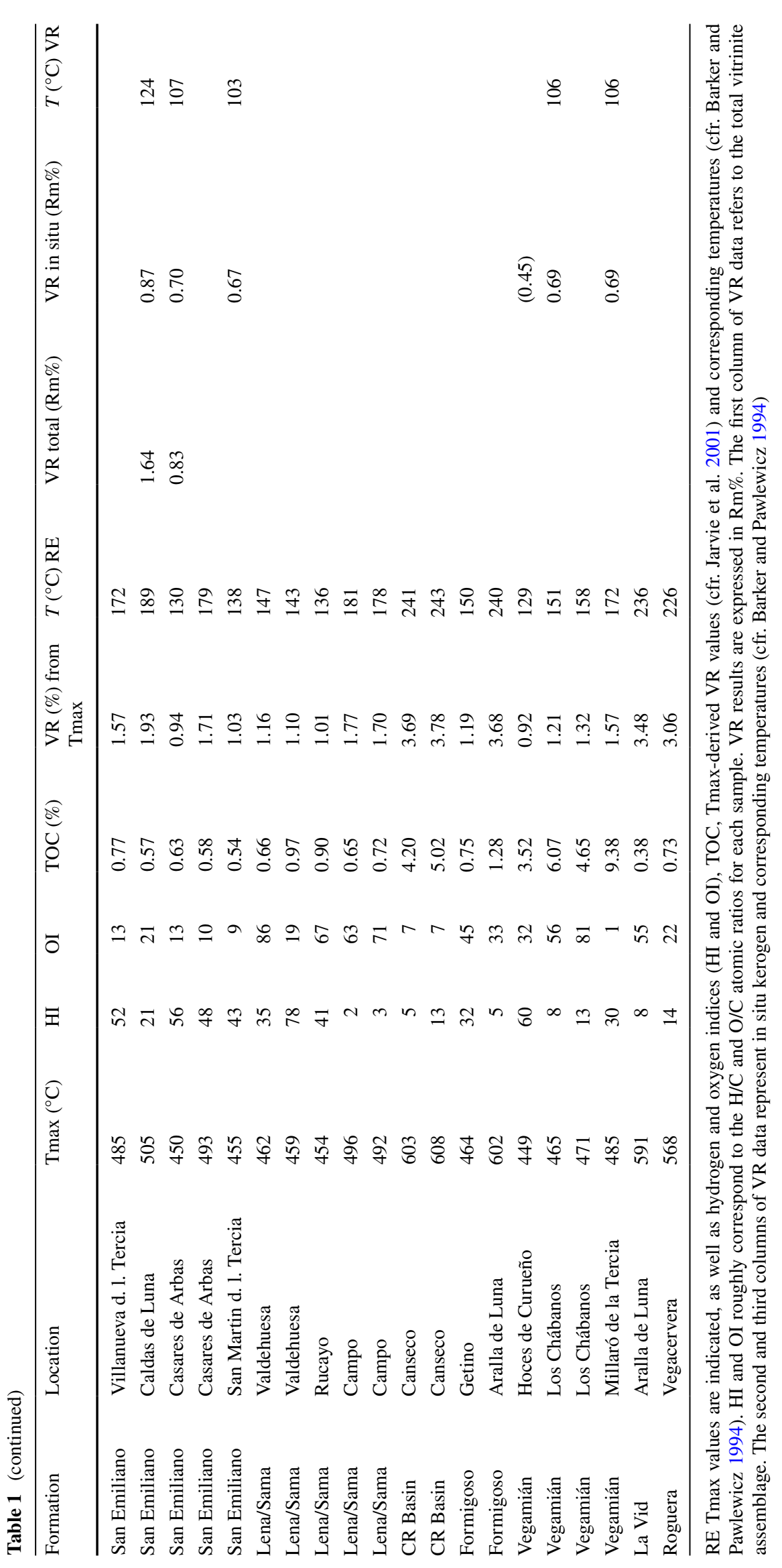


Table 2 Paleotemperatures in ${ }^{\circ} \mathrm{C}$ calculated with common equations for increasing vitrinite reflectance levels

\begin{tabular}{lllll}
\hline Equation & VR 0.75\% & VR 1.0\% & VR 2.0\% & VR 3.0\% \\
\hline Barker (1991) & 118 & 148 & 220 & 262 \\
$\begin{array}{l}\text { Barker and Goldstein } \\
\quad(1990)\end{array}$ & 120 & 155 & 241 & 291 \\
$\begin{array}{l}\text { Barker and Pawlewicz } \\
\quad(1994)\end{array}$ & 112 & 135 & 189 & 225 \\
\hline
\end{tabular}

The difference in paleotemperatures obtained from different equations increases with increasing reflectance level

carbonates in the eastern part of the Bodón Unit, whereas precursor carbonates close to the dolomitized central and western parts are characterized by higher temperatures (up to $203{ }^{\circ} \mathrm{C}$; Fig. 4a). These higher temperatures correlate with areas intensely affected by fracture-related dolomitization and ore mineralization.

Temperatures obtained from KI data from the ambient siliciclastic rocks are remarkably high compared to CAI temperatures (Fig. 4b). In the eastern part of the Bodón Unit, temperatures approach $200{ }^{\circ} \mathrm{C}$ for samples from the San Emiliano Fm., while in the central part all KI data indicate temperatures between 200 and $250{ }^{\circ} \mathrm{C}$, both for the San Emiliano Fm. and the pre-Carboniferous ambient rocks. In the central northern part of the Bodón Nappe, KI-derived paleotemperatures for pre-orogenic rock successions clearly increase towards the León Fault (Fig. 4b). The western part of the Bodón Unit is characterized by slightly lower temperatures, generally around $150^{\circ} \mathrm{C}$, but locally up to $200^{\circ} \mathrm{C}$. The southern part of the Central Coal Basin, north of the León Fault, is characterized by high temperatures between 250 and $300{ }^{\circ} \mathrm{C}$.

VR data for both Stephanian CR and CM basins (Frings et al. 2004; Colmenero et al. 2008) correspond to temperatures ranging from 120 to $240{ }^{\circ} \mathrm{C}$ (Fig. 5a). These relatively high temperatures are believed to be restricted to the Stephanian pull-apart basins because of their fault-controlled settings and their association with intrusions of sills and dykes (Méndez 1985; Frings et al. 2004).

FI trapping temperatures, derived from primary Th values (indicated on Fig. 4a), range from 130 to $150{ }^{\circ} \mathrm{C}$ for dolomite cement in Carboniferous rocks (Gasparrini et al. 2006a). Th values for dolomite cement in Cambrian rocks range between 85 and $105^{\circ} \mathrm{C}$ (Fig. 4a), while true trapping temperatures lie approximately $5^{\circ}-10^{\circ}$ higher (Lapponi et al. 2013). Late diagenetic calcite cement is characterized by trapping temperatures between 115 and $130{ }^{\circ} \mathrm{C}$ (Gasparrini et al. 2006a). Partial re-equilibration to decrepitation of FIs is described by Ayllón et al. (2003) for quartz veins in the Stephanian CM Basin. Here, inclusions were trapped at temperatures between 110 and $120^{\circ} \mathrm{C}$ and re-equilibrated by a short-lived thermal event recording temperatures as high as $300{ }^{\circ} \mathrm{C}$. Ore mineralizations from the Bodón unit are hosted by fracture-related dolomite and record trapping temperatures up to $200{ }^{\circ} \mathrm{C}$ (Paniagua et al. 1993), but did not result in reequilibration of the FIs in the dolomite cements.

In one of the Cambrian AFT samples, as well as in the Stephanian AFT sample, Carrière (2006) observed partial annealing of fission tracks at about $270 \mathrm{Ma}$, indicating insignificant duration of peak thermal conditions to completely anneal the fission tracks (Fig. 4b). The other Cambrian AFT sample indicates complete annealing meaning that temperatures did exceed $110 \pm 10{ }^{\circ} \mathrm{C}$ for more than $10 \mathrm{Ma}$. Most samples of the nearby Sabero Coalfield are completely annealed (Botor and Anczkiewicz 2015).

\section{RE pyrolysis and VR analysis}

Tmax values obtained from RE pyrolysis show a very wide range from 449 to $608{ }^{\circ} \mathrm{C}$ (Table 1), which corresponds to paleotemperatures $130-250^{\circ} \mathrm{C}$ (Table 1; Fig. $5 \mathrm{~b}$ ). These data fall in a slightly cooler range of paleotemperatures as those derived from KI data, but are significantly higher compared to paleotemperatures deduced from CAI data in the study area. The four samples from the Vegamián Fm. show relatively low Tmax values with less variation (corresponding paleotemperatures: $129-172{ }^{\circ} \mathrm{C}$ ), while many samples from the San Emiliano Fm., and the Lena and Sama Groups show the maximum variability (paleotemperatures: $129-228^{\circ} \mathrm{C}$ ). The sample from the Devonian La Vid Group has a very high Tmax of $591{ }^{\circ} \mathrm{C}$ (paleotemperature $236^{\circ} \mathrm{C}$ ). The maximum Tmax values, with very little variation, are recorded for the oldest sample, the Early Paleozoic Formigoso Fm. (Tmax $602{ }^{\circ} \mathrm{C}$; paleotemperature $240{ }^{\circ} \mathrm{C}$ ) and the youngest samples from the Stephanian CR Basin (Tmax $603-608^{\circ} \mathrm{C}$; paleotemperature $241-243^{\circ} \mathrm{C}$ ). Particularly, the San Emiliano Fm. (and its equivalents) shows a very wide range of thermal maturity. Locations most intensely affected by fracture-related dolomitization show RE temperatures around $200{ }^{\circ} \mathrm{C}$ (e.g. the central, western and southeastern parts of the Bodón unit).

Additionally to Tmax values, organic maturity was studied through VR analysis on 18 samples. Tmax-derived VR values obtained for these 18 samples (cfr. Jarvie et al. 2001) show a very wide range (0.92-2.29 Rm\%; Table 1$)$. During VR analysis, two populations of kerogen particles were observed in the kerogen slides of all 15 samples from the San Emiliano Fm., as well as in the distribution of measured VR values (Fig. 6a). The first population consists of less mature organic matter, identified by light to medium brown colors (Fig. 7a). The second population contains higher mature organic matter, identified by dark brown to black colors (Fig. 7a). For the current maturity analysis, only the less mature vitrinite population was analyzed. This led to a narrow range of reflectance in all 


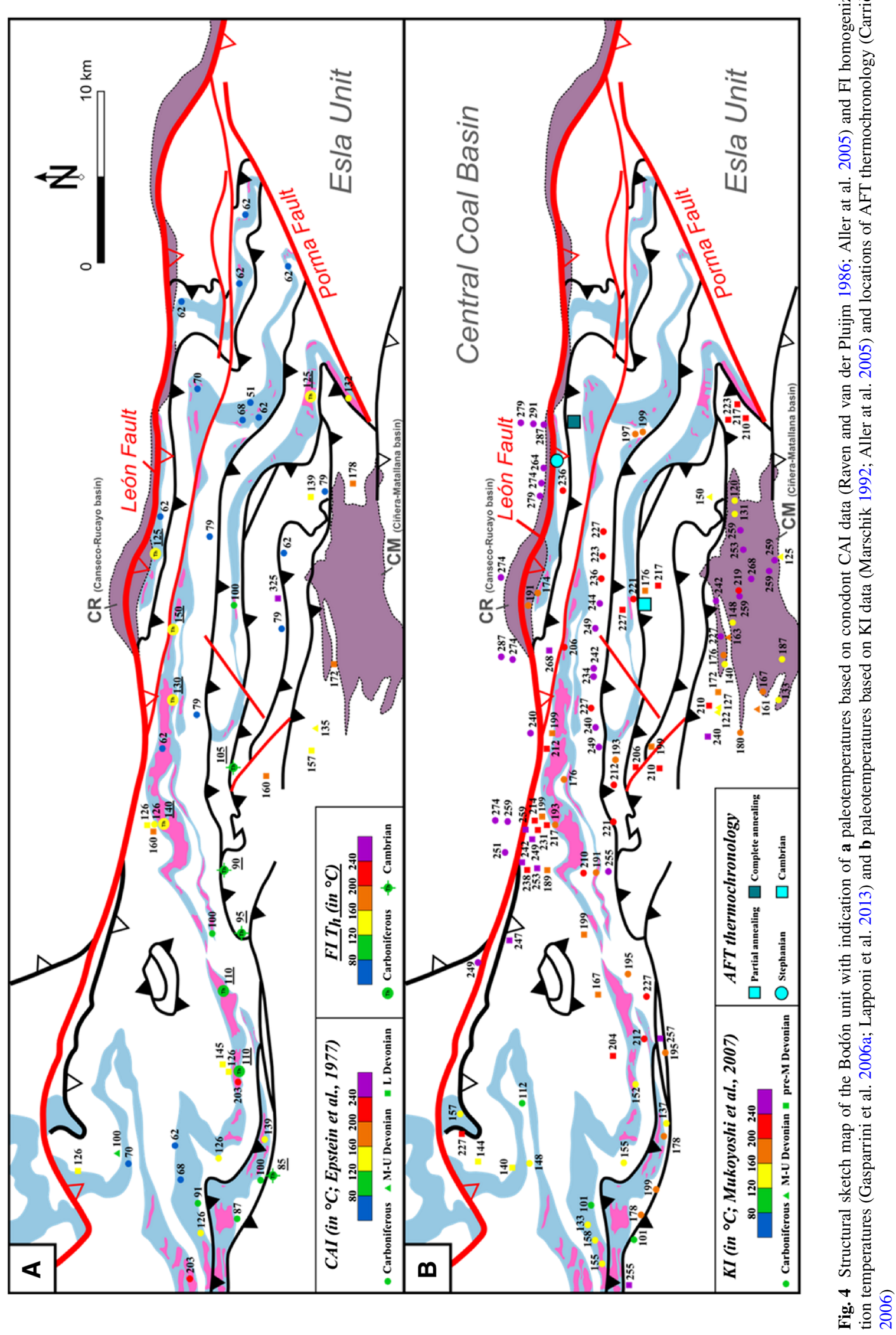




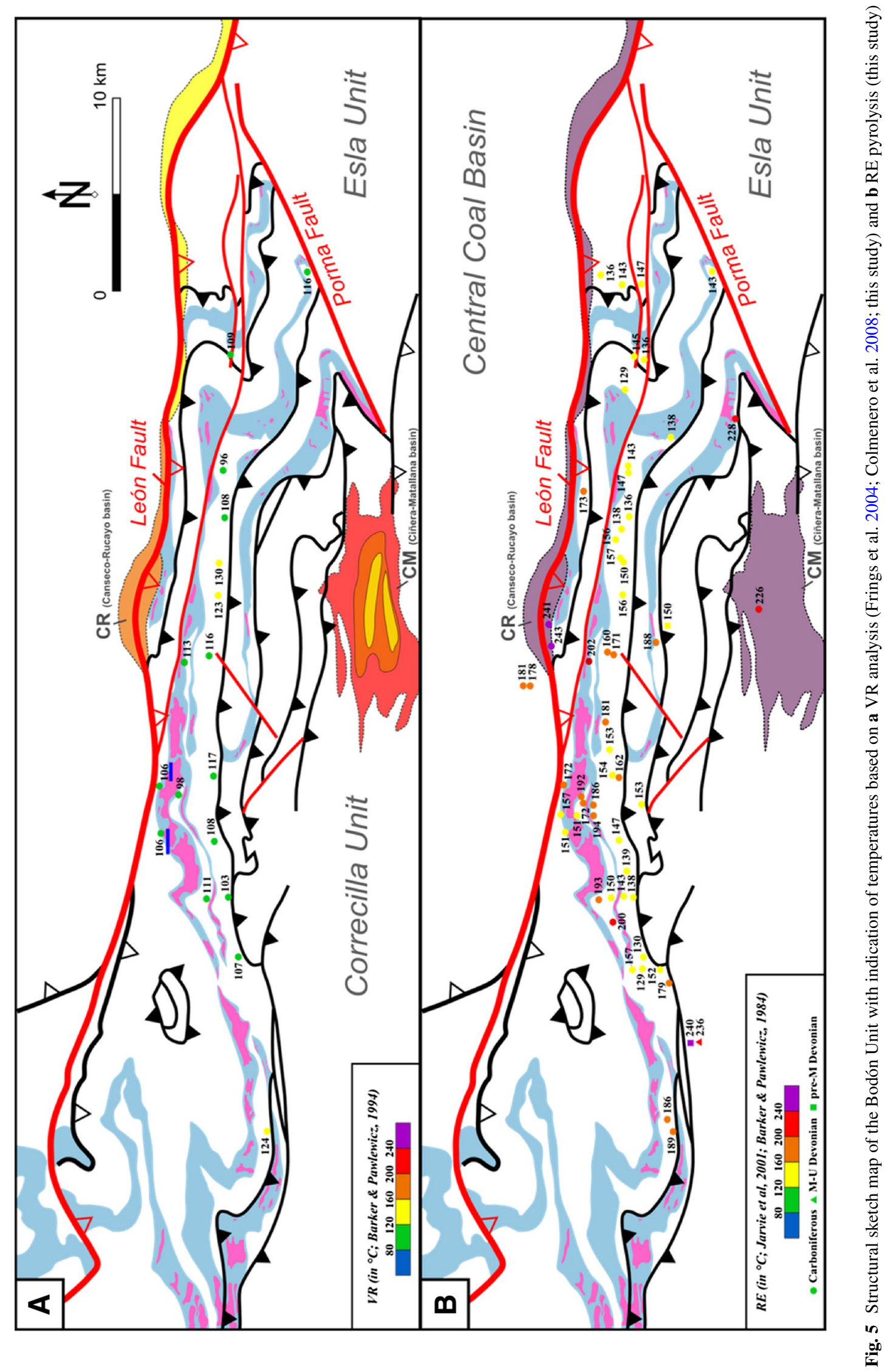



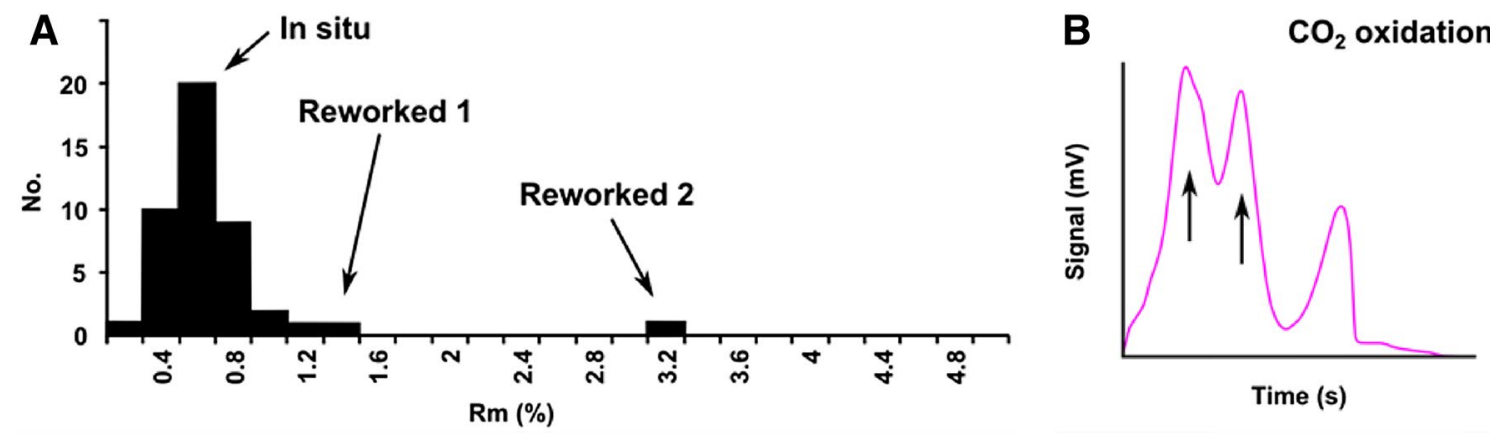

Fig. 6 a Histogram illustrating VR data expressed as $\mathrm{Rm}(\%)$ for sample 46, showing a large population of in situ material and two groups of reworked higher mature material. $\mathbf{b} \mathrm{CO}_{2}$ oxidation pattern from RE analysis for sample 46, showing the occurrence of two types of OM (black arrows). The third peak to the right corresponds to the carbonate content of the sample

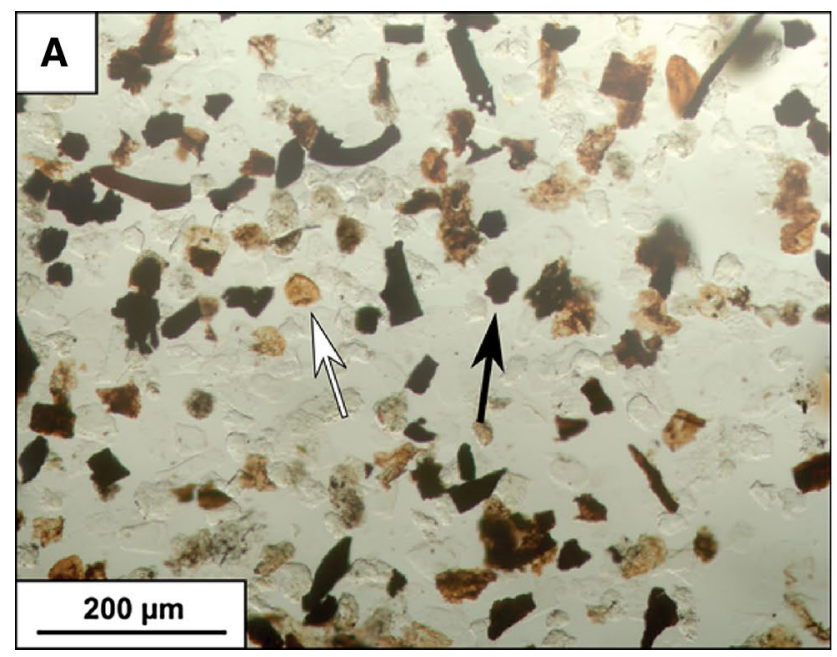

Fig. 7 Kerogen photomicrographs. a Two populations of kerogen can be recognized in these samples from the San Emiliano Fm. Light brown colors (white arrow) characterize the least mature popula-

samples from the San Emiliano Fm. (0.61-0.93 Rm\%; Table 1), showing a much more homogeneous dataset compared to Tmax and Tmax-derived VR values. In the central part of the study area, reflectance values range from 0.79 to $0.93 \mathrm{Rm} \%$ (corresponding paleotemperatures $\left.98-130{ }^{\circ} \mathrm{C}\right)$. Reflectance values are lower in the eastern part (0.61-0.72 Rm\%; paleotemperatures $\left.96-109^{\circ} \mathrm{C}\right)$. At the very western end of the study area, reflectance is high $\left(0.87 \mathrm{Rm} \%\right.$; paleotemperature $\left.124^{\circ} \mathrm{C}\right)$, as well as in the southeastern end, where reflectance increases to $0.79 \mathrm{Rm} \%$ (paleotemperature $116{ }^{\circ} \mathrm{C}$ ). The total vitrinite assemblage for five samples from the San Emiliano Fm. has been analyzed to compare with the Tmax-derived VR values (Table 1). Reflectance data from the total vitrinite assemblages are close to the VR values calculated from Tmax. Except for one sample, all measured VR values are slightly lower. The difference between calculated and measured VR values seems to increase towards higher maturity.

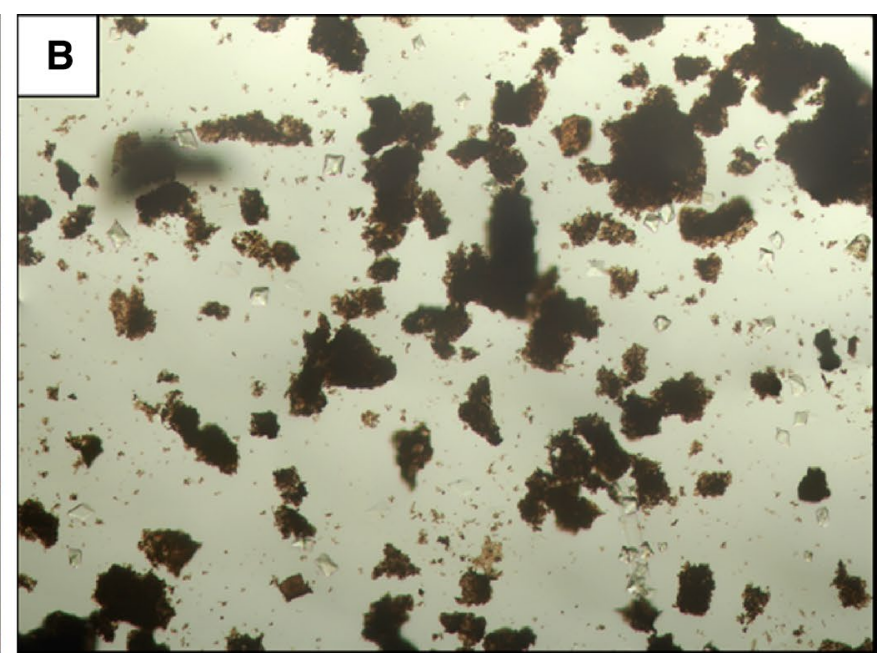

tion, interpreted as in situ, whereas dark brown to black colors (black arrow) characterize the reworked most mature population. b Strongly altered OM in a sample from the Vegamián Fm

Samples from the Vegamián Fm. show strongly altered, poorly preserved organic matter (Fig. 7b). The alteration leads to lower reflectance values compared to the well-preserved vitrinite in other samples. In one sample, all organic matter, including vitrinite, is strongly altered. Therefore the reflectance value is much lower $(0.45 \%)$ compared to the other samples and was excluded from the maturity analysis. In the two other samples (underlined in blue in Fig. 5a), vitrinite was poorly to moderately preserved. Careful selection of the few relatively well-preserved vitrinite particles, and avoiding the altered particles, led to usable VR values, which still might be slightly lower than in well-preserved samples.

The paleotemperatures calculated from VR values of the less mature vitrinite population range from 96 to $130{ }^{\circ} \mathrm{C}$, which is significantly lower compared to the temperatures derived from RE pyrolysis and previous VR data of the CM and CR basins (Fig. 5a; Frings et al. 2004; Colmenero et al. 2008). It has to be taken into account, however, that these 
Stephanian pull-apart basins experienced a different depositional and diagenetic history due to their fault-controlled setting (Méndez 1985; Frings et al. 2004; Botor and Anczkiewicz 2015).

\section{Discussion}

\section{RE pyrolysis versus VR analysis}

The less mature population of kerogen particles identified through optical kerogen analysis represents in situ organic matter recording the in situ basin maturity, while the higher mature population represents reworked organic matter showing the thermal overprint of previous depositional systems. Reflectance values of the total vitrinite population in the five analyzed samples from the San Emiliano Fm. are always higher compared to values of the corresponding in situ vitrinite population, but the differences show a significant variation (Table 1). These differences seem to be controlled mainly by different proportions of highly mature reworked kerogen and less mature in situ kerogen, as observed in the kerogen slides (Fig. 7a). This can also explain the difference between the less mature in situ VR data and the higher mature Tmax-derived VR data, as Tmax (and Tmax-derived VR) is based on whole rock samples, including both the less mature in situ OM and the higher mature reworked OM. The differences between Tmax-derived VR data and in situ VR data are thus controlled by changes in the proportions of higher mature reworked vitrinite and less mature in situ vitrinite.

The occurrence of highly mature reworked OM in the samples from the San Emiliano Fm. supports the hypothesis of reworked detrital illite influencing the KI data recorded for synorogenic successions in the $\mathrm{CZ}$, which has been proposed in several studies (Bastida et al. 1999; Brime et al. 2001; Aller et al. 2005). Indeed, KI-derived temperatures for the San Emiliano Fm. (Fig. 4b) are distinctly higher compared to the temperatures obtained from both in situ (VR) and bulk rock paleothermometers (RE), and are even higher compared to fluid inclusion trapping temperatures in dolomite and quartz gangue minerals. The KI-derived paleotemperatures clearly represent overestimations of the true thermal maturity, most likely due to incorporation of detrital illite. The synorogenic San Emiliano Fm. is composed of siliciclastic sediments filling the foredeep of the Variscan Orogen (Brouwer and van Ginkel 1964). The highly mature detrital illite and the reworked kerogen most likely represent eroded sediments, derived from the deformed and metamorphosed Variscan Orogen to the southwest composed of older pre-orogenic rocks (Julivert 1978; Bastida et al. 1999). The importance of sediment reworking in pre-orogenic siliciclastic successions cannot be assessed for in this study.
Nevertheless, also for these successions, the KI data indicate very high paleotemperatures not in agreement with the real thermal maturity of the sediments. Next to sediment reworking, additional causes for the anomalously high KI-derived temperatures are related to data measurement and processing, and to the empirical equation used for paleotemperature calculation. The KI data of Marschik (1992) were obtained by X-ray diffraction analysis of air-dried samples (Aller et al. 2005). This may result in an overestimation of the KI, as the presence of mixed-layer illite/smectite will modify the X-ray diffractograms in air-dried samples (Junfeng and Browne 2000; Bastida et al. 1999). Empirical equations used to calculate KI-derived temperatures are not widespread in literature, and most of these equations are bound by specific preconditions. The equation of Mukoyoshi et al. (2007) yields the most realistic paleotemperatures for the range of KI data of Marschik (1992) and Aller et al. (2005).

The incorporation of reworked OM and detrital illite limits the interpretation of RE and KI data of the Carboniferous formations for paleothermometry purposes, since they represent synorogenic successions (Marcos and Pulgar 1982; Fig. 2). Maturity analyses and paleothermal studies based on bulk rock techniques, such as RE pyrolysis and the KI of illite crystallinity, have a high risk of failure and erroneous interpretations in most sedimentary systems due to sediment reworking. Ideally, additional data are needed to cross-check the consistency and reliability of these bulk rock techniques. In this study, the presence of two populations of OM with different maturity levels, as observed through optical kerogen analysis, identified the problematic effect of reworking. Next to optical analysis, reworking can also be observed in the pattern of $\mathrm{CO}_{2}$ produced during oxidation, following $\mathrm{RE}$ pyrolysis (Fig. 6b). Although RE pyrolysis can be used for fast screening of thermal maturity levels, additional maturity data are needed to verify the results from RE pyrolysis. This study indicates that a comparison with optical kerogen analysis of vitrinite is needed for more accurate interpretations, especially for the analysis of synorogenic sediments. Through VR analysis, reworked or altered vitrinite particles can be excluded, leading to more reliable and precise information on the thermal maturity of in situ vitrinite.

\section{Comparison with paleothermal data from literature}

The highest temperatures recorded for dolomitization and ore mineralization in the Variscan basement rocks of the Bodón Unit are derived from fluid inclusions in dolomite $\left(130-150{ }^{\circ} \mathrm{C}\right.$ : Gasparrini et al. 2006a) and in quartz gangue minerals in the central part of the study area $\left(200{ }^{\circ} \mathrm{C}\right.$; Paniagua et al. 1993). Trapping temperatures of fluid inclusions indicate the maximum temperatures of hydrothermal fluid flow related to the Post-Variscan thermal event, as they provide a snapshot of the temperature during dolomitization 
and ore mineralization (e.g. Middleton et al. 2001). Hydrothermal fluid flow must have been most important in the central and western parts of the Bodón Unit, as well as in the southeastern part, given the abundance of dolomite and ore mineral deposits in these areas (Fig. 1b). The occurrence of high CAI-derived paleotemperatures in carbonate precursors close to dolomitized and mineralized areas (Fig. 4a) attests the importance of hydrothermal fluid flow in these parts of the Bodón Unit. The episodes of fluid flow must have been sufficiently long to allow the conodont fragments to equilibrate. Likewise, RE-derived temperatures of the EarlyCarboniferous Vegamián Fm. are higher in the central part of the Bodón unit $\left(151-172{ }^{\circ} \mathrm{C}\right)$ compared to the eastern part $\left(129^{\circ} \mathrm{C}\right)$.

Paleotemperatures derived from the in situ VR dataset of the Vegamián and San Emiliano fms. are significantly lower compared to published data for the Stephanian CM and CR basins (Frings et al. 2004; Colmenero et al. 2008; Fig. 5a), highlighting their different thermal histories. They have been more intensely affected by hydrothermal fluid flow and volcanic intrusions due to their fault-controlled setting (Méndez 1985; Frings et al. 2004), and due to the relatively high porosity and permeability of their sedimentary successions compared to the tight Paleozoic basement rocks making up the Bodón unit (Duddy et al. 1994). Althought the RE- and KI-derived temperatures have to be treated with caution given the possible influence of reworked sediments, they seem to confirm the higher thermal maturity of the Stephanian basins (Figs. 4b, 5b).

Temperatures obtained from CAI data for precursor carbonates show baseline values around $60{ }^{\circ} \mathrm{C}$ in the eastern part of the study area, which was less affected by fracturerelated hydrothermal dolomitization and ore mineralization (Figs. 1b, 4a). VR data yield temperatures around $100{ }^{\circ} \mathrm{C}$ for siliciclastics in the same area. This difference of approximately $40{ }^{\circ} \mathrm{C}$ can have several causes related to either the alteration of conodonts or the reflectance of vitrinite. The variety of empirical equations to calculate paleotemperatures from VR data yields divergent paleotemperatures (Table 2), which result in an error range regarding VR-derived paleotemperatures. The possible suppression of vitrinite reflectance (Schito et al. 2016) cannot be assessed for in this study. Regarding the CAI data, it is known that they, compared to other paleothermometers, might be less sensitive. Zhang and Barnes (2007) state that CAI values changing from 1 to $1.5\left(49-62^{\circ} \mathrm{C}\right)$ are not as sensitive as corresponding VR or KI data. Moreover, Raven and van der Pluijm (1986) report a general range of uncertainty of \pm 0.5 , corresponding to a temperature range of $\pm 25^{\circ} \mathrm{C}$. Secondly, the applied heating time of 10 Ma might be an overestimation of the true time of heating. This is unlikely, given the AFT results of Carrière (2006), and Botor and Anckiewicz (2015) which indicate that following the Post-Variscan thermal event temperatures remained high for a significant period of time. Even if the heating time is decreased to $1 \mathrm{Ma}$ on the Arrhenius plot of Eppstein et al. (1977), temperatures around $75{ }^{\circ} \mathrm{C}$ are obtained, which are still significantly lower compared to VRderived temperatures. A third cause might be retardation of the color alteration process due to hydrothermal alteration. Hydrothermal alteration is usually accompagnied by indicative textures and patinas (Voldman et al. 2008), which have indeed been observed in the CZ (Raven and van der Pluijm 1986; Bastida et al. 1999; Blanco-Ferrera et al. 2017).

Next to a lower sensitivity of the CAI technique, a secondary cause which might explain the observed differences between CAI- and VR-derived paleotemperatures, is the influence of deformation partitioning in different mechanical units of the Variscan FFTB. CAI data are obtained from the thick Cambrian and Carboniferous carbonate successions (Fig. 3d) representing rigid carbonate units. Hydrothermal fluid circulation was likely restricted to spaced fractures in these tight units, causing fracture-related dolomitization and ore mineralization, and resulting in a strong thermal overprint of nearby carbonate precursors. VR data on the other hand, are obtained from weak siliciclastic clay-rich successions which were more intensely deformed and might have allowed a more wide-spread circulation of hydrothermal fluids and a more effective heat dissipation in response to the Post-Variscan thermal event.

\section{Hydrothermal versus geothermal dolomitization}

In the field of ore geology, hydrothermal activity refers to the action of hot waters directly related to igneous activity, in contrast with geothermal waters which are not related with igneous intrusions (Robb 2005). In dolomitization studies, hydrothermal generally applies to dolomitization by fluids with temperatures at least $10{ }^{\circ} \mathrm{C}$ higher than those experienced by the surrounding rocks, including both carbonate precursors and ambient siliciclastics (Stearns et al. 1935; White 1957; Machel and Lonnee 2002). The current dolomitization model for the dolomite geobodies in the Bodón Unit assumes that thermal convection of hydrothermal marine-derived brines resulted in fracture-related porous dolomites (Gasparrini et al. 2006b). This was based on the difference between FI trapping temperatures of $130-150{ }^{\circ} \mathrm{C}$ (Gasparrini et al. 2006a) and CAI-derived paleotemperatures of $70-95^{\circ} \mathrm{C}$ in Carboniferous carbonate formations (Raven and van der Pluijm 1986).

Our study indicates that in the eastern part of the study area, CAI-derived paleotemperatures of undolomitized precursor carbonate rocks average around $60{ }^{\circ} \mathrm{C}$, which is likely an underestimation of their true thermal maturity. Siliciclastic ambient rocks are characterized by VR-derived temperatures around $100{ }^{\circ} \mathrm{C}$. Since dolomitization and ore mineralization were more important in the central and western parts 
of the study area, one can assume that these lower temperatures are the result of Pre-Variscan burial and high crustal heat flow during the Post-Variscan thermal event. It confirms the hydrothermal nature of dolomitization $\left(130-150^{\circ} \mathrm{C}\right)$ and ore mineralizations (up to $200{ }^{\circ} \mathrm{C}$ ) which are clearly related to positive temperature anomalies in the central and western parts of the study area.

\section{Conclusions}

The thermal maturity of Paleozoic rocks in the southern Cantabrian Zone (the Iberian Variscan foreland fold-andthrust belt) has been investigated to better constrain the thermal conditions of Late-Variscan fluid flow which caused widespread dolomitization and ore mineralization. Maximum temperatures experienced by both carbonate precursor and ambient siliciclastic rocks have been assessed based on a compilation of published paleothermal data (CAI, KI, VR, and FI) combined with newly acquired RE pyrolysis and VR analysis data.

Both RE and KI data from synorogenic successions yield paleotemperatures that are anomalously high compared to in situ VR data and CAI data. Optical kerogen analysis of VR samples revealed an important amount of reworked highly mature kerogen, giving evidence for significant input of reworked sediments in these synorogenic units. The presence of reworked sediments, most likely eroded material from higher metamorphic zones of the Variscan Orogen, critically affects maturity analysis through bulk rock techniques like RE pyrolysis, KI and VR analysis of total vitrinite populations. This is a general problem in many sedimentary systems, where maturity analyses based on bulk rock data are limited by uncertainties and the risk of erroneous misinterpretations. During optical kerogen analysis, in situ and reworked kerogen populations can be identifed. Using only the reflectance values of in situ populations significantly increases the accuracy and reliability of the maturity data and minimizes the risk of failure of maturity analyses.

CAI-derived paleotemperatures for carbonate precursor rocks not affected by intense fluid circulation average around $60{ }^{\circ} \mathrm{C}$, and are attributed to burial and increased crustal heat flow following lithospheric delamination. Paleotemperatures within these carbonate rock units increase towards dolomitized and mineralized zones, which formed during PostVariscan fluid flow at temperatures up to $200{ }^{\circ} \mathrm{C}$ (Paniagua et al. 1993). Siliciclastic ambient rocks affected by burial and high crustal heat fluxes have a higher average thermal maturity, corresponding to temperatures around $100{ }^{\circ} \mathrm{C}$ (based on in situ VR data). The different thermal maturity of carbonate and siliciclastic rocks is likely caused by a difference in analytical techniques used to obtain CAI and VR data and their corresponding paleotemperatures. Conodont fragments were likely not as sensitive to the thermal overprint compared to VR, and the color alteration process might have suffered from hydrothermal alteration. A secondary cause to explain the difference in thermal maturity might be a different response to Variscan compression and orocline formation of rigid precursor carbonates and softer ambient siliciclastics which caused the hot fluids to circulate in a different manner. Circulation was confined along spaced fractures through the carbonates, and was more widespread through the siliciclastics, resulting in more efficient heat transport.

Massive fracture-related dolomitization of Cambrian and Carboniferous carbonates of the southern Cantabrian Zone occurred at temperatures between 90 and $150{ }^{\circ} \mathrm{C}$ (based on FIs). Undisturbed ambient siliciclastic rocks experienced temperatures around $100{ }^{\circ} \mathrm{C}$, whereas this temperature might have been lower for precursor carbonates. Dolomitization was thus caused by hydrothermal fluids, circulating in thermal disequilibrium with the precursor carbonate rocks. The positive temperature anomalies recorded in the precursor carbonate rocks by CAI data broadly correlate with the occurrence of dolomitization and ore mineralization. This implies that, in similar settings, mapping the thermal maturity anomalies within carbonate precursors could be used as an exploration tool for porous hydrothermal dolomitic geobodies and ore mineralization.

Acknowledgements This study was funded by Research Foundation-Flanders (FWO). Additional funding was also provided by the IAS 2014 Grant Scheme. Rock-Eval measurements were performed at IFPEN (France). Daniel Pillot and Géremie Letort are kindly acknowledged for assistence with the analyses. We thank Elisabeth Bemer (IFPEN), head of the "water-rock interaction" project, who provided additional funding for vitrinite reflectance analyses.

\section{References}

Aller J, Brime C (1985) Deformación y metamorfismo en la parte Sur de la Cuenca Carbonífera Central (NO de España). C R X Congr Int Strat Géol Carbonif 3:541-548

Aller J, Bastida F, Brime C, Pérez-Estaún A (1987) Cleavage and its relation with metamorphic grade in the Cantabrian Zone (Hercynian of North-West Spain). Sci Géol Bull 40(3):255-272

Aller J, Valín ML, García-López S, Brime C, Bastida F (2005) Superposition of tectono-thermal episodes in the southern Cantabrian Zone (foreland thrust and fold belt of the Iberian Variscides, NW Spain). Bull Soc Geol Fr 176:487-498

Alonso JL, Suárez-Rodríguez A, Rodríguez-Fernández LR, Farias P, Villegas FJ (1990) Hoja del Mapa Geológico Nacional de España (1:50000), memoria 104 (La Pola de Gordón). IGME, Madrid

Alonso JL, Pulgar JA, García-Ramos JC, Barba P (1996) Tertiary basins and Alpine tectonics in the Cantabrian Mountains (NW Spain). In: Friend PF, Dabrio CJ (eds) Tertiary basins of Spain: the stratigraphic record of crustal kinematics. Cambridge University Press, Cambridge, pp 214-227

Alonso JL, Marcos A, Suárez A (2009) Paleogeographic inversion resulting from large out of sequence breaching thrusts: The 
León Fault (Cantabrian Zone, NW Iberia). A new picture of the external Variscan thrust belt in the Ibero-Armorican Arc. Geol Acta 7(4):451-473

Ayllón F, Bakker RJ, Warr LN (2003) Re-equilibration of fluid inclusions in diagenetic-anchizonal rocks of the Ciñera-Matallana coal basin (NW Spain). Geofluids 3:49-68

Bahamonde JR, Merino-Tomé O, Della Porta G, Villa E (2015) Pennsylvanian carbonate platforms adjacant to deltaic systems in an active marine foreland basin (Escalada Fm., Cantabrian Zone, NW Spain). Basin Res 27(2):208-229

Barker CE (1991) Implications for organic maturation studies of evidence of a geologically rapid increase and stabilization of vitrinite reflectance at peak temperature: Cerro Prieto geothermal system, Mexico. AAPG Bull 75(12):1852-1863

Barker CE, Goldstein RH (1990) Fuid-inclusion technique for determining maximum temperature in calcite and its comparison to the vitrinite reflectance geothermometer. Geology 18:1003-1006

Barker CE, Pawlewicz MJ (1994) Calculation of vitrinite reflectance from thermal histories and peak temperatures. A comparison of methods. In: Mukhopadhyay PK, Dow WG (eds) Vitrinite reflectance as a maturity parameter: applications and limitations. ACS Symp Ser 570:216-229

Bastida F, Brime C, García-López S, Sarmiento GN (1999) Tectonothermal evolution in a region with thin-skinned tectonics : the western nappes in the Cantabrian Zone (Variscan belt of NW Spain). Int J Earth Sci 88:38-48

Bastida F, Brime C, García-López S, Aller J, Valín ML, Sanz-López J (2002) Tectono-thermal evolution of the Cantabrian Zone (NW Spain). Cuad Del Museo Geomin 1:105-123

Blanco-Ferrera S, Sanz-López J, García-López S, Bastida F (2017) Tectonothermal evolution of the northeastern Cantabrian zone (Spain). Int J Earth Sci 106(5):1539-1555

Botor D (2012) Hydrothermal fluids influence on the thermal evolution of the Stephanian sequence, the Sabero Coalfield (NW Spain). Geol Geophys Environ 38:369-393

Botor D, Anczkiewicz AA (2015) Thermal history of the Sabero coalfield (Southern Cantabrian Zone, NW Spain) as revealed by apatite fission track analyses from tonstein horizons: implications for timing of coalification. Int J Earth Sci 104:1779-1793

Brime C (1981) Postdepositional transformations of clays in Palaeozoic rocks of Northwest Spain. Clay Miner 16:421-424

Brime C, García-López S, Bastida F, Valín ML, Sanz-López J, Aller J (2001) Transition from diagenesis to metamorphism near the front of the Variscan regional metamorphism (Cantabrian zone, Northwestern Spain). J Geol 109:363-379

Brouwer A, van Ginkel AC (1964) La succession Carbonifère dans la partie méridionale des montagnes Cantabriques (Espagne NordOuest). Comptes Rendus, 5ème Congrès sur le Carbonifère, Paris 1963, vol 1, pp 307-319

Cantrell D, Swart P, Hagerty R (2004) Genesis and characterization of dolomite, Arab-D Reservoir, Ghawar Field, Saudi Arabia. GeoArabia 9(2):11-36

Carrière KL (2006) Neoproterozoic to Holocene tectonothermal evolution of the southern Cantabrian mountains NW Iberia, revealed by apatite fission-track thermochronology. Dissertation, University of Heidelberg

Chesnel V, Samankassou E, Merino-Tomé Ó, Fernández LP, Villa E (2015) Facies, geometry and growth phases of the Valdorria carbonate platform (Pennsylvanian, Northern Spain). Sedimentology 63:60-104

Colmenero JR, Prado JG (1993) Coal basins in the Cantabrian mountains, Northwestern Spain. Int J Coal Geol 23:215-229

Colmenero JR, Suárez-Ruiz I, Fernández-Suárez J, Barba P, Llorens $\mathrm{T}$ (2008) Genesis and rank distribution of Upper Carboniferous coal basins in the Cantabrian mountains, Northern Spain. Int J Coal Geol 76:187-204
Copard Y, Disnar JR, Becq-Giraudon JF (2002) Erroneous maturity assessment given by Tmax and HI Rock-Eval parameters on highly mature weathered coals. Int J Coal Geol 49:57-65

Corretgé LG, Suárez O (1990) Igneous rocks of the Cantabrian/Palentine Zone. In: Dallmeyer RD, Martínez García E (eds) Premesozoic geology of Iberia. Springer, Berlin, pp 72-79

Crespo JL, Moro MC, Fadón O, Cabrera R, Fernández A (2000) The Salamón gold deposit (León, Spain). J Geochem Explor 71:191-208

Dallmeyer RD, Martínez García E (1990) Pre-mesozoic geology of Iberia. Springer, Berlin

Dietrich B (2005) Numerical modeling as a means to enhance genetic sedimentary basin interpretation: a case study of the Southern Cantabrian Basin (NW Spain). Dissertation, University of Heidelberg

Duddy IR, Green PF, Bray RJ, Hegarty KA (1994) Recognition of the thermal effects of fluid flow in sedimentary basins. In: Parnel J (ed) Geofluids: origin, migration and evolution of fluids in sedimentary basins. Geol Soc SP 78:325-345

Eberl DD (1993) Three zones for illite formation during burial diagenesis and metamorphism. Clay Clay Miner 41:26-37

Eichmüller K (1985) Die Valdeteja Formation: Aufbau und Geschichte einer oberkarbonischen Karbonatplattform. (Kantabrisches Gebirge, Nordspanien) Facies 13:45-154

Epstein AG, Epstein JB, Harris LD (1977) Conodont color alterationan index to organic metamorphism. US Geol Surv Prof Paper 995:1-27

Espitalié J, Laporte JL, Madec M, Marquis F, Leplat P, Paulet J (1977) Méthode rapide de caractérisation des roches mères, de leur potentiel pétrolier et de leur degré d'évolution. Rev I Fr Petrol 32:23-45

Espitalié J, Deroo G, Marquis F (1985a) La pyrolyse Rock-Eval et ses applications. Première Partie. Rev I Fr Petrol 40:563-579

Espitalié J, Deroo G, Marquis F (1985b) La pyrolyse Rock-Eval et ses applications. Deuxième Partie. Rev I Fr Petrol 40:755-784

Espitalié J, Deroo G, Marquis F (1985c) La pyrolyse Rock-Eval et ses applications. Troisième Partie Rev I Fr Petrol 41:73-89

Evers HJ (1967) Geology of the Leonides between the Bernesga and Porma rivers, Cantabrian Moutains, NW Spain. Leidse Geol Meded 41:83-151

Feng M, Zitong Q, Ping S, Jian Z, Yanzhong T, Maolong X (2016) Evidences for hydrothermal dolomite of Sinian Dengying formation in Gaoshiti-Moxi area, Sichuan basin. Acta Petrol Sin 37:587-598

Fillon C, Pedreira D, van der Beek PA, Huismans RS, Barbero L, Pulgar JA (2016) Alpine exhumation of the central Cantabrian mountains, Northwest Spain. Tectonics 35:339-356

Frings K, Warr L (2012) Hydrothermally altered mudrock of the Ciñera-Matallana coal basin, Cantabrian Zone, northern Spain. Eur J Miner 24:1017-1029

Frings K, Lutz R, de Wall H, Warr LN (2004) Coalification history of the Stephanian Ciñera-Matallana pull-apart basin, NW Spain: Combining anisotropy of vitrinite reflectance and thermal modeling. Int J Earth Sci 93:92-106

Fukuchi R, Fujimoto K, Kameda J, Hamahashi M, Yamaguchi A, Kimura G, Hamada Y, Hashimoto Y, Kitamura Y, Saito S (2014) Changes in illite crystallinity within an ancient tectonic boundary thrust caused by thermal, mechanical, and hydrothermal effects: an example from the Nobeoka Thrust, southwest Japan. Earth Planets Space 66:116

García-López S, Bastida F, Brime C, Aller J, Valín ML, Sanz-López J, Méndez CA, Menéndez-Álvarez JR (1999) Los episodios metamórficos de la Zona Cantábrica y su contexto estructural. Trabajos Geol Univ Oviedo 21:177-187

Gasparrini M, Bakker RJ, Bechstädt T (2006a) Characterization of dolomitizing fluids in the Carboniferous of the Cantabrian 
Zone (NW Spain): a fluid-inclusion study with cryo-raman spectroscopy. J Sediment Res 76:1304-1322

Gasparrini M, Bechstädt T, Boni M (2006b) Massive hydrothermal dolomites in the southwestern Cantabrian Zone (Spain) and their relation to the Late Variscan evolution. Mar Petrol Geol 23:543-568

Gleadow AJW, Duddy IR (1981) A natural long-term track annealing experiment for apatite. Nucl Tracks 5:169-174

Goldstein RH, Reynolds TJ (1994) Systematics of fluid inclusions in diagenetic minerals. Society for Sedimentary Geology Short Course 31

Gómez-Fernández F, Both RA, Mangas J, Arribas A (2000) Metallogenesis of $\mathrm{Zn}-\mathrm{Pb}$ carbonate-hosted mineralization in the southeastern region of the Picos de Europa (Central Northern Spain) province: geologic, fluid inclusion, and stable isotopes studies. Econ Geol 95:19-40

Gong Z, Langereis CG, Mullender TAT (2008) The rotation of Iberia during the Aptian and the opening of the Bay of Biscay. Earth Planet Sci Lett 273:80-93

Guggenheim S, Bain DC, Bergaya F, Brigatti MF, Drits VA, Eberl DD, Formoso MLL, Galán E, Merriman RJ, Peacor DR, Stanjek H, Watanabe T (2002) Report of the Association Internationale pour l'Etude des Argiles (AIPEA) Nomenclature Committee for 2001: order, disorder and crystallinity in phyllosilicates and the use of the 'Crystallinity Index'. Clay Miner 37:389-393

Gutiérrez-Alonso G, Fernández-Suárez J, Weil AB (2004) Orocline triggered lithospheric delamination. Geol Soc Am Spec Pap 383:121-130

Gutiérrez-Alonso G, Johnston ST, Weil AB, Pastor-Galán D, Fernández-Suárez J (2012) Buckling an orogen: the Cantabrian Orocline. GSA Today 22:4-9

Gutiérrez-Alonso G, Collins AS, Fernández-Suárez J, Pastor-Galán D, González-Clavijo E, Jourdan F, Weil AB, Johnston ST (2015) Dating of lithospheric buckling: 40Ar/39Ar ages of syn-orocline strike-slip shear zones in northwestern Iberia. Tectonophysics 643:44-54

Hurley NF, Budros R (1990) Albion-Scipio and Stoney Point fields, USA, Michigan basin. In: Beaumont EA, Foster NH (eds) Stratigraphic traps I: AAPG treatise of petroleum geology. Atlas of Oil and Gas Fields, Tulsa, pp 1-37

Jarvie DM, Claxton BL, Henk FB, Breyer JT (2001) Oil and Shale gas from the Barnett Shale, Ft. Worth Basin, Texas. AAPG National Convention, Denver, 3-6 June 2001

Julivert M (1971) Décollement tectonics in the Variscan Cordillera of northwest Spain. Am J Sci 270:1-29

Julivert M (1978) Hercynian orogeny and Carboniferous palaeogeography in northwestern Spain: a model of deformation-sedimentation relationships. Z Dtsch Geol Ges 29:565-592

Junfeng J, Browne PRL (2000) Relationschip between illite crystallinity and temperature in active geothermal systems of New Zealand. Clay Clay Miner 48:139-144

Karweil J (1955) Die Metamorphose der Kohlen vom Standpunkt der physikalischen Chemie. Z Dtsch Geol Gesellsch 107:132-139

Kübler B (1967) La cristallinité de l'illite et les zones tout à fait supérieures du métamorphisme. Etages Tectoniques, Colloque de Neuchâtel 1966, à la Baconnière, Neuchâtel, pp 105-121

Kübler B (1968) Evaluation quantitative du métamorphisme par cristallinité de l'illite. Bull Centre Rech Pau 2:385-397

Lafargue F, Marquis F, Pillot D (1998) Rock-Eval 6 applications in hydrocarbon exploration, production, and soil contamination studies. Rev I Fr Petrol 53:421-437

Lapponi F, Bechstädt T, Boni M, Banks DA, Schneider J (2013) Hydrothermal dolomitization in a complex geodynamic setting (Lower Palaeozoic, northern Spain). Sedimentology 61:411-443
Lobato L, García-Alcalde JL, Sánchez de Posada LC, Truylos J, Villegas FJ (1984) Hoja del Mapa Geológico Nacional de España (1:50000), Memoria 104 (Boñar). IGME, Madrid

Machel HG, Lonnee J (2002) Hydrothermal dolomite - a product of poor definition and imagination. Sediment Geol 152:163-171

Marcos A (1968) La tectónica de la Unidad de la Sobia-Bodón. Trab Geol Univ Oviedo 2:59-87

Marcos A, Pulgar JA (1982) An approach to the tectonostratigraphic evolution of the Cantabrian Foreland thrust and fold belt, Hercynian Cordillera of NW Spain. Neues Jahrb Geol P 163(2):256-260

Marín JA (1997) Estructura del Domo de Valsurbio y borde surorental de la Región del Pisuerga-Carrión (Zona Cantábrica, NO de España). Dissertation, University Oviedo

Marschik R (1992) Der Übergang von Diagenese zur sehr niedergradigen Metamorphose im externen Variszikum (Kantabrische Zone), NW Spanien. Dissertation, University of Heidelberg

Martínez-García E (1983) Permian Mineralizations in the Cantabrian Mountains (North-West Spain). In: Schneider HJ (ed) Mineral Deposits of the Alps and of the Alpine Epoch in Europe. Springer, Berlin, pp 259-274

Martín-González F, Barbero L, Capote R, Heredia N, Gallastegui $G$ (2012) Interaction of two successive Alpine deformation fronts: constraints from low-temperature thermochronology and structural mapping (NW Iberian Peninsula). Int J Earth Sci 101:1331-1342

Méndez A (1985) Estudio de la evolución de los carbones de la Cuenca Ciñera-Matallana, León. Dissertation, University of Oviedo

Merriman RJ, Frey M (1999) Patterns of very low-grade metamorphism in metapelitic rocks. In: Frey M, Robinson D (eds) Lowgrade metamorphism. Blackwell Science Limited, London, pp 61-107

Middleton DWJ, Parnell J, Green PF, Xu G, McSherry M (2001) Hot fluid flow events in Atlantic margin basins: an example from the Rathlin Basin. In: Shannon PM, Haughton PDW, Corcoran DV (eds) The petroleum exploration of Ireland's offshore basins, 188. Special Publications, London, pp 91-105

Mukoyoshi H, Hara H, Omori K (2007) Quantitative estimation of temperature conditions for illite crystallinity: comparison to vitrinite reflectance from the Chichibu and Shimanto accretionary complexes, eastern Kyushu, Southwest Japan. Bull Geol Surv Jpn 58:23-31

Muñoz-Quijano IN (2015) Hydrothermal dolomitization of Paleozoic successions in Northern Spain: petrophysical properties and structural control. Dissertation, University of Heidelberg

Muñoz-Quijano IN, Gutiérrez-Alonso G (2007) Modelo de evolución topográfica en el NO de la Península Ibérica durante la delaminación litosférica al final de la Orogenia Varisca. Geogaceta 43:43-46

Paniagua A, Fontboté L, Fenoll Hach-Alí P, Fallick AE, Moreiras DB, Corretgé LG (1993) Tectonic setting, mineralogical characteristics, geochemical signatures and age dating of a new type of epithermal carbonate-hosted, precious metal-five element deposits: the Villamanín area (Cantabrian Zone, northern Spain). In: Fennoll Hach-Alí P, Torres-Ruiz J, Gervilla F (eds) Current research in geology applied to ore deposits. Proceedings of the 2nd SGA biennial meeting, Granada, pp 531-534

Pérez-Estaún A, Bastida F, Alonso JL et al (1988) A thin-skinned tectonics model for an arcuate fold and thrust belt : the Cantabrian Zone (Variscan Ibero-Armorican Arc). Tectonics 7:517-537

Phipps GG (1989) Exploring for dolomitized Slave Point carbonates in northeastern British Columbia. Geophysics 54:806-814

Price PB, Walker RM (1963) Fossil tracks of charged particles in mica and the age of minerals. J Geophys Res 68(16):4847-4862

Pulgar JA, Alonso JL, Espina RG, Marín JA (1999) La deformación alpina en al basamento varisco de la Zona Cantábrica. Trab Geol Univ Oviedo 21:283-294 
Raven JGM (1983) Conodont biostratigraphy and depositional history of the Middle Devonian to Lower Carboniferous in the Cantabrian Zone (Cantabrian Mountains, Spain). Leidse Geol Meded 52:265-339

Raven JGM, van der Pluijm BA (1986) Metamorphic fluids and transtension in the Cantabrian Mountains of northern Spain: an application of the conodont colour alteration index. Geol Mag 123:673-681

Rejebian VA, Harris AG, Huebner JS (1987) Conodont color and textural alteration: An index to regional metamorphism, contact metamorphism, and hydrothermal alteration. Geol Soc Am Bull 99:471-479

Robb L (2005) Introduction to ore-forming processes. Blackwell, Oxford

Samankassou E (2001) Internal structure and depositional environment of Late Carboniferous mounds from the San Emiliano Formation, Cármenes Syncline, Cantabrian mountains, Northern Spain. Sediment Geol 145:235-252

Sanchez de Posada LC, Martinez Chacon ML, Mendez Fernandez C, Menendez Alvarez JR, Truyols J, Villa E (1990) Carboniferous Pre-Stephanian rocks of the Asturian-Leonese Domain (Cantabrian zone). In: Dallmeyer RD, Martínez-García E (eds) PreMesozoic geology of Iberia. Springer, Berlin, pp 24-33

Schito A, Corrado S, Aldega L, Grigo D (2016) Overcoming pitfalls of vitrinite reflectance measurements in the assessment of thermal maturity: the case history of the lower Congo basin. Mar Petrol Geol 74:59-70

Seibert L (1986) Fazies und Paläogeographie des Unter-Karbon (Alba Formation) im Kantabrischen Gebirge (Nordspanien). Dissertation, University of Tübingen

Stearns ND, Stearns HT, Waring GA (1935) Thermal springs in the United States. Contributions to the hydrology of the United States. Water Supply Paper 679-B:59-191

Suárez Rodríguez A, Heredia N, López Díaz F, Toyos JM, Rodríguez Fernández LR, Gutiérrez G (1991) Hoja del Mapa Geológico Nacional de España (1:50000), memoria 102 (Los Barrios de Luna). IGME, Madrid

Suggate RP (1959) New Zealand coals, their geological setting and its influence on their properties. In: Owen RE (ed) New Zealand Department of Scientific Industrial Research Bulletin 13:1-112

Teichmüller M (1982) Application of coal petrological methods in geology including oil and natural gas prospecting. In: Stach
E, Mackowsky MTh, Teichmüller M, Taylor GH, Chandra D, Teichmüller R (eds) Stach's textbook of coal petrology. Gebrüder Borntraeger, Berlin, pp 381-413

Teichmüller M (1987) Organic material and very low grade metamorphism. In: Frey M (ed) Low-temperature metamorphism. Chapman and Hall, Glasgow, pp 114-161

Tissot BP, Welte DH (1978) Petroleum formation and occurrence. A new approach to oil and gas exploration. Springer, Berlin

van Ginkel AC (1965) Carboniferous fusulinids from the Cantabrian Mountains (Spain). Leidse Geol Meded 34:1-255

Voldman GG, Albanesi GL, Do Campo M (2008) Conodont palaeothermometry of contact metamorphism in Middle Ordovician rocks from the Precordillera of western Argentina. Geol Mag 145:449-462

Wagner RH, Bowman MBJ (1983) The position of the Bashkirian/Moscovian boundary in West European chronostratigraphy. Newsl Stratigr 12:132-161

Wagner GA, van den Haute P (1992) Fission-track dating. Enke, Stuttgart

Wagner RH, Winkler Prins CF, Riding RE (1971) Lithostratigraphic units of the lower part of the Carboniferous in Northern León, Spain. Trab Geol Univ Oviedo 4:603-663

Weh A, Krumm S, Clauer N, Keller M (2001) The late orogenic history of the southeastern Cantabrian mountains: illite-crystallinity and $\mathrm{K}-\mathrm{Ar}$ data. EUGXI abstract

Weil AB, Gutiérrez-Alonso G, Johnston ST, Pastor-Galán D (2013) Kinematic constraints on buckling a lithospheric-scale orocline along the northern margin of Gondwana: a geologic synthesis. Tectonophysics 582:25-49

White DE (1957) Thermal waters of volcanic origin. Geol Soc Am Bull 68:1637-1658

Winkler Prins CF (1968) Carboniferous Productidina and Chonetidina of the Cantabrian Mountains (NW Spain): systematics, stratigraphy and palaeoecology. Leidse Geol Meded 43:41-126

Zamarreño I (1972) Las lithofacies carbonatadas del Cámbrico de la Zona Cantábrica (NW España) y su distribución paleogeográfica. Trab Geol Univ Oviedo 5:3-118

Zhang S, Barnes CR (2007) Late Ordovician-Early Silurian conodont biostratigraphy and thermal maturity, Hudson Bay Basin. B Can Petrol Geol 55:179-216 